\title{
Informática, vida privada y los proyectos chilenos sobre protección de datos
}

\section{Christian Suárez Crothers}

Mucho se ha escrito últimamente acerca del impacto de la informática en las libertades individuales y, especialmente, en la denominada esfera de privacidad de los individuos. Ellas son siempre sensibles al desarrollo tecnológico, como parece evidente, si adoptamos el criterio de Marshall Mc Luhan, según el cual el modo de transmisión de una cultura influye sobre esta cultura y la transforma ${ }^{1}$. Para el profesor Francis Balle, de otra parte, "los medios de difusión de comunicación, lejos de ser medios perfectamente neutros, determinan los modos de pensar, de obrar y de sentir de la sociedad" 2 .

En el mismo sentido evidenciamos el temor de Linant de Bellefonds cuando afirma que "... la informática no es una técnica políticamente neutra: la informatización participa de una dinámica propia que favorece el reforzamiento de los centros de poder (instituciones del Estado y grandes empresas) en perjuicio de las libertades individuales" ${ }^{\prime \prime}$.

Francis Balle distingue en la historia de la comunicación posterior a la invención de la imprenta, tres grandes quiebres o rupturas ${ }^{4}$. La primera ruptura corresponde a la que denomina como la era de las comunicaciones a distancia. Epoca que comienza con la invención del telégrafo eléctrico en 1837 y que culmina, pasando por la invención del

\footnotetext{
1 Ver Francis Balle. Médias et Sociétés, Montchrestien, París, 1994, p. 17.

2 Ibidem, p. 17 (la traducción es nuestra).

3 Linant de Bellefonds. L'informatique et le Droit. Que Sais-Je? Presses Universitaires de France, Paris, 1981, p. 53.

4 Francis Balle. Op.cit., p. 59.
} 
teléfono, con la aparición de la radio y la televisión transmitidas, ambas, por medio de ondas hertzianas.

Una segunda ruptura, se produce a partir de los años 50 con el paso de la electrónica a la microelectrónica, proceso que se produce gracias a los circuitos integrados y, luego, a los microprocesadores. Esta época se caracteriza porque junto al desarrollo de la informática, la instalación de fuentes de cables y de satélites, expande a escala planetaria la presencia de la radio y la televisión.

Pero, finalmente, la ruptura más impresionante en esta historia de las comunicaciones, es la que comienza a producirse entre los años 1985 y 1990, y que es llamada desde 1991-1992, tanto en Japón como en los EE.UU. la "era de la comunicación global". Esta nueva y singular etapa se caracteriza porque es la informática la que "federa" los universos por mucho tiempo separados de lo audiovisual, la teledifusión y las telecomunicaciones.

Pero, ¿en qué sentido la tecnología influye en la esfera de la libertad? A nuestro juicio, desde dos puntos de vista. Primero, desde aquél que Stafford Beer llama de "adaptación" a las nuevas formas de cultura que la tecnología importa ${ }^{5}$ y que implica diversas fases, que van desde la comprensión del fenómeno hasta el rediseño de las instituciones ${ }^{6}$ y, segundo, desde la generación de nuevas formas de cautelar la libertad, que no son sólo una adaptación al desarrollo tecnológico sino una respuesta directa del Derecho de la libertad ante la nueva tecnología. Ya hemos señalado antes que solo así explicamos la aparición de institutos como el derecho a la imagen, inconcebibles sin la invención de la fotografía y la secuela de medios de difusión de imágenes que le suceden.

Sin embargo, es un error pensar que las nuevas tecnologías y especialmente las tecnologías relativas a las comunicaciones son per se un atentado a la libertad.

No siempre en la historia ello se ha manifestado así, más bien en ocasiones ha ocurrido lo contrario, como cuando en el renacimiento

5 Quizás podríamos mencionar como un ejemplo de esta adaptación del hombre a las tecnologías en el ámbito de las libertades la propuesta de Jean d'Arcy, en 1969, de reconocer el derecho del hombre a la comunicación, como una manera de superar el margen estrecho del llamado derecho a la información. Para d'Arcy, su propuesta es más conforme a "... nos acquis technologiques les pluts récents". Citado por Balle en op.cit., p. 264.

6 Stafford Beer. Diseñando la libertad. Breviarios del Fondo de Cultura Económica, Madrid, 1977, p. 100. 
italiano florece -y principalmente en Venecia- la actividad de los llamados menanti, predecesores de los actuales periodistas, y que operan con anterioridad a la invención de la imprenta. Ellos sufren la ofensiva de los poderes establecidos y de la tentación de la censura. En este sentido bien puede decirse que la invención de la imprenta es un paso gigantesco en la conquista de la libertad, no sólo porque permitirá el acceso masivo de la población a la cultura, otrora privilegio de unos pocos, sino también porque será el gran instrumento del futuro Estado liberal y parlamentario deseoso de debate, de discusión y de confrontación de ideas.

El desarrollo de los medios de comunicación de masas, por su parte, ha permitido también, de la mano con la telefonía, la radio y la televisión, una expansión de la libertad hacia grandes masas humanas que han permanecido en un submundo de explotación y de ignorancia durante siglos.

Ciertamente se han derivado también efectos perniciosos, como el llamado efecto herodiano, introducido por los mass media y que se caracteriza por la emulación de comportamientos y estilos de vida que responden a esquemas culturales ajenos al mundo de sus receptores, con el desencadenamiento subsiguiente de complejos fenómenos de alienación humana.

Pero, pese a todo, no compartimos nosotros una visión catastrofista del desarrollo tecnológico y más bien nos alienamos dentro de aquellas opciones que propician su control democrático para el resguardo de las libertades.

Es dentro de esta perspectiva como debemos situar el tema de la libertad frente al fenómeno informático. Por cierto, el criterio será el de imaginar las múltiples amenazas que el fenómeno puede conllevar para la libertad personal, quizá sobredimensionando el efecto real de su impacto en la vida social. Es decir, nuestro criterio es aquí un criterio pro-libertatis, deseoso de detectar los peligros y de encontrar adecuadas garantías. En consecuencia, no nos constituimos en enemigos del progreso técnico, simplemente ponemos atención en su impacto sobre la libertad.

Bien ha podido afirmar el profesor Balle que "desde Gutenberg, los media son el lugar y el centro de todas las libertades del pensamien-

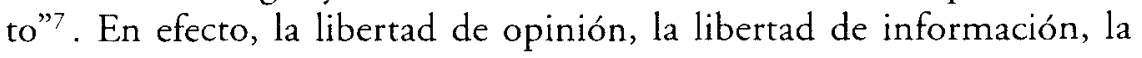

7 Francis Balle. Op. cit., p. 247. 
libertad de prensa $^{8}$, la libertad de imprenta no son sino manifestaciones de este hecho.

Sin embargo, y en forma paralela, las declaraciones de derechos del S. XVIII previenen sobre los abusos de estas libertades, especialmente de la libertad de prensa.?

Más contemporáneamente, el artículo $19^{\circ}$ del Pacto de Derechos Civiles y Políticos deja claro que estas libertades comportan deberes y responsabilidades especiales y que deben ser sometidas a ciertas restricciones, siempre por medio de la ley. ¿Cuáles son estas restricciones?: a) el respeto a los derechos o a la reputación de los demás; $\mathrm{y}, \mathrm{b}$ ) la salvaguarda de la seguridad nacional, el orden público, la salud o la moralidad públicas ${ }^{10}$. En términos similares prescriben las convenciones americana y europea de derechos humanos.

Las legislaciones han ido adoptando en el tiempo mayores precauciones en esta materia, en la que ya no se confía tanto en la solución pretoriana. Así, por ejemplo, en Francia, a través de la Ley de 17 de julio de 1970 , se modificaron los artículos $368^{\circ}$ a $370^{\circ}$ del Código Civil de esa Nación, creando como nuevas infracciones: a) el delito de captación de la palabra o de la imagen de una persona; b) el delito de conservación, divulgación o utilización de la palabra o imagen de una persona; y, c) el montaje de documentos o de imágenes.

Vitorio Frosini ha podido reconocer tres modos de atentar contra la vida privada en la civilización tecnológica: a) En el plano físico, y de manera directa, recurriendo a los nuevos instrumentos de reconocimiento óprico y acústico; b) en el plano psicológico, mediante diversas técnicas para obtener del individuo informaciones sin que éste se de cuenta del significado que estas tienen en la revelación de su vida privada; y, c) en forma indirecta, mediante la recolección, comparación,

8 Suecia es el primer país en instituir la libertad de prensa por medio de una ley dictada en 1766 .

9 El artículo $11^{\circ}$ de la Declaración de los Derechos del Hombre y de los Ciudadanos entrega a la ley la regulación de los abusos de las libertades de opinión y de imprenta.

10 A partir de 1956 con la puesta en boga por Siebert, Peterson y Schramm, de la doctrina de la responsabilidad de los media se pone mayor atención al efecto que los medios de comunicación tienen sobre las libertades, y particularmente sobre la vida privada. El error de la prensa se dice conduce al error en la opinión del público. Por ello se concibe a la prensa como un verdadero servicio público y, por tanto, sometido también a ciertas cargas. 
adición o agregación de datos, incluso minuciosos, que son procesados por ordenadores electrónicos ${ }^{11}$.

Este último es el que aquí nos convoca.

La actividad de registro, ya sea manual o automatizado, ofrece en esta época múltiples posibilidades. Casi cabe decir que no hay actos de nuestra vida que no sean susceptibles de ser registrados, desde el nacimiento a nuestra muerte. No sólo el Estado realiza esta ingente labor de registro, censos periódicos y acumulación de información para los más variados fines, como los que se realizan a través de las instituciones educacionales o de salud, los datos recopilados por la policía o los servicios de inteligencia del Estado y las Fuerzas Armadas y, en fin, a través también del registro cada vez más intenso que realizan las empresas privadas en su afán de competencia, de información y de predominio en los mercados, registro que alcanza a los deudores del comercio y de la banca.

Por cierto que esta actividad de registro afecta la esfera de privacidad de los individuos. Un sinnúmero de datos son utilizados por los más diversos operadores, a veces sin que existan regulaciones adecuadas que permitan un control personal y jurídico de los mismos, sin que las legislaciones arbitren instrumentos que faciliten su conocimiento, acceso y rectificación o, lo que es peor, cuando no se contemplan instancias de control que importen una suerte de garantía institucional frente a la utilización de estos datos y a su incorporación en registros a partir de los cuales es posible compararlos, confrontarlos y levantar un perfil de la personalidad no aceptado por las personas.

Esta situación que hoy es estimada como usual, que ha dado lugar a algunos autores para temer grandes transformaciones en el mundo social y político y a pensar que la vigilancia de los poderosos, el panopticón de los antiguos, se convierta en una efectiva realidad, en un mundo que para unas minorias que controlan la información se hace cada vez más transparente.

En Derecho público la transparencia se predica de las actividades del Estado y sus voceros, pero es una vieja conquista del Derecho el que el Estado y, hoy se dirá que también los particulares, no se inmiscuyan en aquél ámbito de la vida que no puede quedar entregado a la

11 Vitorio Frosini. Informática y Derecho. Editorial Temis, Bogotá, 1988, p.70. 
transparencia, simplemente porque sería faltar a las normas mínimas del respeto a la dignidad de las personas, a su pleno derecho a conducir sus destinos de manera libre y voluntaria, y aun en contra de las convenciones en uso. Es humano invocar el derecho al olvido, es humano reparar las faltas pasadas, es humano hacerlo sin que los demás conozcan de todo ello. En sentido liberal clásico, hay que respetar ese derecho de hacer todo aquello que no lesione intereses de la sociedad o de terceros, como hay que respetar que el sujeto que determina qué parte de ese hacer debe quedar privado del conocimiento ajeno, es el propio individuo, en orden a la salvaguarda de su dignidad.

Se comprende, entonces, que la problemática anterior haya dado lugar a que los juristas enfrentaran estos nuevos desafíos, buscando utilizar los viejos moldes que ha concebido el Derecho. La primera tentación es la de buscar una manera de conceder a los sujetos un derecho, un derecho subjetivo, que le permite resguardar su libertad amenazada, su derecho a la personalidad, la conservación de su imagen, la no intromisión en ámbitos que considera reservados. Y es así como se ha intentado dar al derecho a la intimidad, vida privada o a la riservatezza una fuerza de irradiación capaz de cobijar bajo su seno estas violaciones a lo que se considera la intimidad informática.

Pero para ello había que salvar un primer escollo. El derecho a la intimidad siempre ha sido concebido como una libertad negativa, como un derecho de defensa. De este modo, era necesario dar un nuevo salto dialéctico y transformar por completo la vieja noción del derecho a la intimidad. Había que concebir este derecho en forma más amplia, entendiendo que también él posibilita a los individuos el control de las informaciones que a su juicio deben permanecer reservadas.

Esta nueva perspectiva del derecho a la intimidad haría, por tanto, aplicable y plenamente suficiente la protección ya consagradas por los textos constitucionales a la protección de la privacidad, sin que por ello fuese necesario recurrir a figuras nuevas, derechos nuevos y discutibles.

También junto a esta perspectiva está la confianza en que son los jueces, a través del proceso de determinación de la norma y su aplicación al caso concreto, de su actividad interpretativa, en quienes debía recaer el mayor esfuerzo de delimitación entre los usos informáticos, el derecho a la intimidad y su relación con los demás derechos a los que se relaciona.

Sostenemos aquí, que esta perspectiva no da respuesta adecuada al problema que se pretende resolver y que no es buen expediente confiar 
en soluciones que hayan de surgir exclusivamente por medio de la actividad pretoriana.

En este sentido es digno de alabanza que los legisladores chilenos hayan comprendido esta necesidad, y que ya desde hace algún tiempo, se venga perfilando en Chile la idea de legislar en estas materias.

\section{¿Cuáles son las razones que invitan a desarrollar una legislación espe- cífica?}

\section{Los condicionamientos de la sociedad informática al Estado de Derecho.}

La construcción del Estado ha supuesto, desde sus inicios, un uso ingente del instrumental proporcionado por la técnica. La necesidad de organización de los estados nacionales y de afirmación de su independencia y diferencia frente a los demás, ha implicado históricamente la gestión de una burocracia administrativa creciente, la organización de la producción y el consumo y la racionalización de la actividad de Defensa ${ }^{12}$. En este sentido puede afirmarse que la técnica, como racionalidad instrumental ${ }^{13}$ es y ha sido siempre"... la plataforma giratoria... de la modernidad"14.

Sin embargo, la Revolución francesa ha significado el aceleramiento más profundo de esta dimensión racionalizadora, cuya base teórica y filosófica se encuentra en los propios principios de la Declaración de los Derechos del Hombre y del Ciudadano ${ }^{15}$.

12 Cfr. Alain Touraine. Crítica de la Modernidad. Ediciones Temas de Hoy, Madrid, 1993 , p. 192.

13 También para García Pelayo, "...la mera presencia de la racionalidad instrumental no parece definir la época postmoderna o ni siquiera la moderna; más bien una de las características de la modernidad es que la técnica, hasta entonces empírica y plenamente artesanal, comienza a sustentarse sobre la racionalidad científica objetiva ... Por otra parte ... nuestra civilización tecnológica no se plantea tanto qué con las cosas -y, entre ellas, la Razón- cuanto cómo se hacen las cosas o cómo funcionan. Y bajo estos supuestos, se abre la vía al desarrollo de una racionalidad destinada a lograr objetivos concretos e inmediatos quizá sin meditar las consecuencias que puedan tener sobre la totalidad o sobre la consecución de otros objetivos." En entrevista publicada en Anthropos, Barcelona, núm. 59, 1986, pp. 16-20, por Carlos Gurméndez, bajo el título: "Sobre la Historia y otros Temas", contenida en sus Obras Completas, Centro de Estudios Constitucionales, Madrid, 1991, pp. 3288.

14 Alain Touraine. Op. cit. p. 192.

15 Cfr. Eduardo García de Enterría. La lengua de los derechos. La formación del 
El Estado de Derecho ha sido la forma jurídica en que se ha externalizado este proceso de racionalización que se acrecienta con la Revolución y con el triunfo del ideal burgués que estructura la libertad sobre la base de la igualdad formal de los ciudadanos. La ley se convierte entonces en el principal instrumento de conformación del Estado Democrático de Derecho, de la distribución de sus poderes, y del desarrollo del mercado con la apertura de las barreras internas, la eliminación de los privilegios y la consagración del principio de la libre circulación de los bienes y de las personas. La ley, como instrumento de la libertad, de acuerdo con la más pura y clásica noción kantiana, como factor desencadenante del progreso.

Esta relación entre el Estado con el Derecho y la ley como principio de libertad sufre una transformación con el advenimiento de la sociedad industrial y con los automatismos y condicionamientos que impone el proceso técnico a la sociedad, a los individuos y al propio Estado. Identificar al Estado con el proceso técnico importa -ha dicho Forsthofla negación práctica de la libertad, idéntica o muy parecida a aquella que se produciría con la total indiferencia del Estado frente a su desenvolvimiento ${ }^{16}$. El Estado debe entonces cumplir con su papel de regulación legal normativa, para someter, dentro de lo posible, el desarrollo técnico al marco específico que exija la sociedad.

Esta situación descrita por Forsthof respecto de la República Federal Alemana como paradigma de la sociedad industrial, se vería modifica-

Derecho Público europeo tras la Revolución Francesa. Alianza Universidad, Madrid, 1994, p. 109.

16 Señala Ernst Forsthof (El Estado de la Sociedad Industrial. Instiruro de Estudios Políticos, Madrid, 1975) tres posibilidades de plantear la pregunta sobre la relación entre la realización técnica y el orden político estatal. La primera aproximación consiste en identificar ambas nociones, de manera que se visualice al Estado como el "señor y promotor del proceso técnico", sirviendo la técnica de instrumento del poder estatal. Una segunda perspectiva es aquella en que el Estado se limita a establecer, a fijar el marco dentro del cual se desarrolla la realización técnica y, finalmente, la tercera consistiría en que el Estado deje vía libre al desarrollo técnico pasando a cumplir sólo una función complementaria dentro de la sociedad industrial. La primera aproximación, de carácter utópico ha sido las que han intentado realizar las sociedades comunistas e importan "necesariamente la negación de la libertad individual" (p. 63) y la sin atender a otro orden de razones ... (convirtiéndose) ... por fuerza (en) indiferente ante lo humano". (p. 67). La segunda perspectiva, es entonces la más adecuada. "La sociedad industrial sería incapaz de sobrevivir sin una transformación social así realizada. La necesidad de regulaciones legal normativas por parte de la sociedad es enorme ..." (p. 75), dice Forsthof, para contener y someter a límites los efectos del desarrollo autónomo del proceso técnico. 
do en el Estado de la sociedad post-industrial, en el que el marco de las relaciones de estratificación y poder se transforman muy principalmente, de acuerdo con el siguiente esquema propuesto por Daniel Bell ${ }^{17}$ :

\begin{tabular}{|c|c|c|c|}
\hline Pre-industrial & Industrial & Post-industrial & \\
\hline Recursos & Tierra & Maquinaria & Conocimientos \\
\hline Locus social & $\begin{array}{l}\text { Granja } \\
\text { Plantaciones }\end{array}$ & Empresa de negocios & $\begin{array}{l}\text { Universidad } \\
\text { Centros de investigación }\end{array}$ \\
\hline Figuras dominantes & $\begin{array}{l}\text { Terratenientes } \\
\text { Miditares } \\
\end{array}$ & Hombres de negocios & \begin{tabular}{|l|} 
Cientificos \\
Investigadores \\
\end{tabular} \\
\hline Medios de poder & $\begin{array}{l}\text { Control directo por la } \\
\text { fuerza }\end{array}$ & $\begin{array}{l}\text { Influencia indirecta sobre las } \\
\text { decisiones políticas }\end{array}$ & $\begin{array}{l}\text { Equilibrio de fuerzas } \\
\text { técnico-políricas } \\
\text { Franquicias y derechos }\end{array}$ \\
\hline Base de clase & $\begin{array}{l}\text { Propiedad } \\
\text { Fuerza militar }\end{array}$ & $\begin{array}{l}\text { Propiedad } \\
\text { Organización política } \\
\text { Preparación técnica }\end{array}$ & $\begin{array}{l}\text { Preparación técnica } \\
\text { Organización política }\end{array}$ \\
\hline Acceso & $\begin{array}{l}\text { Herencia } \\
\text { Apropiación mediante } \\
\text { ejércitos }\end{array}$ & $\begin{array}{l}\text { Herencia } \\
\text { Parronazgo } \\
\text { Educación }\end{array}$ & $\begin{array}{l}\text { Educación } \\
\text { Movilización } \\
\text { Cooptación }\end{array}$ \\
\hline
\end{tabular}

La sociedad post-industrial que se constituye a partir de la segunda mitad del presente siglo es propiamente la sociedad de la información o "sociedad informatizada" 18 . Se caracteriza, desde un punto de vista positivo, en palabras de Vittorio Frosini por crear "una nueva posibilidad de unificación de la sociedad humana, con la circulación de la información extendida a todos..."19. El desarrollo de las tecnologías de la información ha originado de este modo una nueva revolución cultural, un cambio antropológico "...que modifica la imagen del hombre anterior y la convierte en la de un hombre puesto en los confines del automatismo antropomórfico..."20.

La revolución informática constituye para el jurista italiano un cambio de civilización, tan importante como el que dio paso de la comunicación oral a la escritura, a la invención de la imprenta, y al efecto de comunicación instantánea de las mass media ${ }^{21}$. A través de ella se hace

17 Daniel Bell. El advenimiento de la sociedad post-industrial. Alianza Editorial, Madrid, 1991 , p. 412.

18 Jean-Francois Lyotard. La Condición Postmoderna. Ediciones Cátedra S.A., Madrid, 1989, p.13.

19 Vittorio Frosini. Informática y Derecho. Editorial Temis S.A., Bogotá-Colombia, 1988 , p. 34.

20 Ibidem, p. 34.

21 Ibidem, p. 84. 
posible el desarrollo de la inteligencia artificial y la acumulación de grandes cantidades de información.

Como ha expresado Francisco Romero Marín: "Estamos recorriendo el camino de una sociedad apoyada en un flujo de innovaciones técnicas materiales, como ha sido la llamada sociedad industrial, a otra que se asienta sobre un flujo de innovaciones técnicas abstractas, así como sobre la organización del aumento de saber en corporaciones especializadas en el desarrollo del conocimiento" ${ }^{22}$.

Surge, por tanto, una necesidad de comprensión de este nuevo fenómeno desde la perspectiva del Derecho Público. Al respecto ha dicho García Pelayo que "...lo característico de nuestro tiempo, por debajo de las apariencias y las discrepancias, es constituir la época de la civilización científico-tecnológica, fenómeno complejo de describir pero al que nos atrevemos a sintetizar como una etapa histórica caracterizada por la vigencia de una nueva realidad creada por el hombre, que supera las limitaciones e incluso en muy amplia medida la necesidad o la coacción del mundo natural, pero que se impone tan enérgicamente a través de lo que Schelsky llama la "legalidad (o la coacción) de las cosas (Sachgesetzlichkeit y Sachzwang)...(que introduce)... una legalidad de índole bien distinta de la natural o de la jurídica, pero no por eso menos, sino más determinante que ellas" ${ }^{23}$. Sobre los efectos del desarrollo tecnológico, agrega el distinguido constitucionalista español, que: "... el desarrollo tecnológico ha dilatado nuestro horizonte y posibilidades vitales hasta límites a veces ni siquiera soñados, ...(y)... ha puesto a nuestra disposición un gran número de bienes y servicios y... nos ha liberado de tradicionales limitaciones y servidumbres. Pero -también al igual que otros- pienso que simultáneamente nos ha creado fuertes dependencias frente a las grandes organizaciones y sistemas complejos que hace posible tal desarrollo: que nos somete a un proceso de homogeneización a costa de nuestras particularidades personales y colectivas; que acrece el gap entre los pueblos desarrollados y subdesa-

22 Francisco Moreno Marín. "La Informática en la accividad del Estado. la Administración de Justicia". En: Revista de la Facultad de Derecho de la Universidad Complutense, N ${ }^{\circ}$ 12, Monográfico "Informática y Derecho", Madrid-Sepriembre, 1986, p. 306.

23 Manuel García Pelayo. "QQué libros y autores han configurado de manera decisiva nuestra época?" Entrevista publicada en febrero de 1972 en Imagen, revista del Instituto Nacional para la Cultura y Bellas Artes, Caracas, contenida en sus Obras Completas, Tomo III, Centro de Estudios Constitucionales, Madrid, 1991, p. 3252. 
rrollados; que amenaza algunas de nuestras libertades tradicionales; que crea grandes posibilidades de control de nuestras vidas por parte del poder político..." 24 .

¿En qué medida este tipo de sociedad produce efectos sobre la estructura clásica del Estado de Derecho? Es la cuestión que intentaremos responder en los epígrafes siguientes.

\section{La tendencia a la concentración de poderes.}

Ha afirmado H. Schelsky que: "la soberanía del Estado no se manifiesta sólo por el hecho de que monopolice el uso de la violencia (Max Weber) o decida el estado de excepción (Carl Schmitt), sino ante todo por el hecho de que decide el grado de eficacia de todos los medios técnicos que existen en su seno, y de que se reserva aquéllos cuya eficacia es más elevada y puede prácticamente situarse a sí mismo fuera del campo de aplicación de esos medios técnicos que impone a los otros". ${ }^{25}$

Por cierto que esta actividad de dominio del Estado sobre la técnica puede ser positiva si se analiza en los términos en que Forstoff enfocaba el problema para la sociedad industrial, pero también tiene un cierto carácter ilusorio si se aquilata la relativa autonomía con la que el desarrollo técnico se produce.

Esta tendencia a la concentración de poderes suele ser invocada por los autores como uno de los principales efectos a que conducen las tecnologías de la información. Lyotard lo explica en el cambio de legitimidad del saber en una sociedad informatizada, en que los modelos emancipatorios o idealistas dan paso a una forma de saber que sólo recibe su fuente de legitimación del poder, del "control sobre el contexto" que es dable proporcionar a la informatización generalizada. Remarca el filósofo francés, que: "El Estado y/o la empresa abandona el relato de legitimación idealista o humanista para justificar el nuevo objetivo: en la discusión de los socios capitalistas de hoy en día, el único objetivo creíble es el poder. No se compran savants, técnicos y aparatos para saber la verdad, sino para incrementar el poder" ${ }^{\prime 26}$.

24 Manuel García Pelayo. Op. cit.: "Sobre la Historia y...", p. 3289.

25 H. Schelsky, H. Der Mensch in der Wissenschaftlichen Zeitalter. Colonia, 1961, pp.

24 y ss. Citado por J.F. Lyotard, op. cit., p. 30.

26 Jean-Francois Lyotard. op. cit., pp. 86 y 87. 
Ahora bien, tal y como señala Lyotard, la dinámica de crecimiento del poder no es sólo predicable de las instituciones públicas y del Estado, sino también, y de manera muy significativa, del sector privado: de las grandes corporaciones financieras, bancarias, industriales y de telecomunicaciones. En palabras de este autor: "El "redespliegue" económico en la fase actual del capitalismo, ayudado por la mutación de técnicas y tecnologías, marcha a la par ... con un cambio de función de los Estados. Digamos, para ser breves, que las funciones de regulación y, por tanto, de reproducción, se les quitan y se les quitarán más y más a los administradores y serán confiadas a autómatas. La cuestión principal se convierte y se convertirá más aún en poder disponer de las informaciones que estos últimos deberán tener memorizadas con objeto de que tomen las decisiones adecuadas. La disposición de las informaciones es y será más competencia de expertos de todos los tipos. La clase dirigente es y será cada vez más la de los "decididores". Deja de estar constituida por la clase política tradicional, para pasar a ser una base formada por jefes de empresa, altos funcionarios, dirigentes de los grandes organismos profesionales, sindicales, políticos, confesionales". ${ }^{27}$

Este traspaso de poderes a quienes ejerzan el control de la "tecnoburocracia" puede implicar, ciertamente, si es que ya no constituye una realidad bien patente, un déficit importante de democracia, que altere, como veremos, el principio tradicional de separación de poderes. Es a ello a lo que apunta Lyotard cuando sugiere una mutación en las funciones del Estado. Si "la cuestión del Estado se encuentra estrechamente imbricada con la del saber científico" 28 el mayor peligro habrá de consistir en que ni siquiera desde el punto de vista moral es posible construir una teoría de la justicia que descanse en las hipótesis de Rawls sobre el "velo de la ignorancia". Indudablemente, el fenómeno de la transparencia de lo público, lo será cada vez más para quienes ejerzan el control sobre las informaciones, para la casta de los llamados por Lyotard "decididores", que controlan la tecnoburocracia, pero no para las grandes masas de los ciudadanos, que inmersos en las llamadas "narrativas tradicionales", permanecerán -si los controles democráticos no se acentúan- en un velo de la ignorancia muy cercano al del oscurantismo.

27 Ibidem, p. 35 .

28 Ibidem, p. 61. 
Tal circunstancia, por tanto, no es indiferente ni trivial para la teoría del Estado y de la Constitución, más aún si se considera que uno de los objetivos de las disposiciones constitucionales es el perfeccionamiento de las reglas del consenso social produciendo nuevos paradigmas ${ }^{29}$.

\section{El reforzamiento de la Administración}

En consecuencia, como nos recuerda Moreno Marín, "existe el riesgo de la acumulación de grandes masas de información sobre los ciudadanos y la aparición de un nuevo corporativismo entre los poseedores, reales o presuntos, de las nuevas técnicas" ${ }^{30}$.

En el ámbito público es el Poder Ejecutivo quien goza de las mayores posibilidades técnicas y presupuestarias para la utilización de los nuevos medios que proporciona la tecnología informática. ${ }^{31}$ El Gobierno, en su función administradora, no puede prescindir de un instrumento tan eficaz como el que las nuevas técnicas le proporcionan. Por medio de su uso, el Estado puede "recoger, almacenar, clasificar, racionalizar y transmitir los datos e informaciones necesarios para la gestión de toda clase de servicios y actividades ... (como asimismo) ... difundir el contenido de los registros informatizados a altas velocidades e intercambiar los datos disponibles en todas las direcciones" 32 .

El peligro de concentración de informaciones en la administración o en sus agencias, ha sido ejemplificado por Pérez Luño, en los EE.UU., "el país que cuenta con la tecnología informática más avanzada" y, en donde, a juicio del filósofo del Derecho español, se han producido las mayores consecuencias sociopolíticas que el fenómeno pueda producir, partiendo por las ocasionadas en el caso Watergate. Señala el profesor Pérez Luño que en el sector público de ese país, “... varios millones de dossiers sobre actitudes individuales se hallan en manos de la C.I.A. y del Pentágono. Para comprobar la progresión de los datos almacenados baste tener presente que el National Crime Information Center del F.B.I. disponía en 1967 de 346.124 dossiers, que pasaron a ser 3.330 .220 en

29 Ibidem, cfr., p. 60.

30 Francisco Moreno Marín. Op. cit., pp. 314.

31 Ibidem, cfr., p. 310

32 Ibidem, p. 313. 
1971 y que hoy se han multiplicado por 19; en idéntico período, por lo que se refiere a informaciones transmitidas, se pasó de 7 a 25 millones" 33 .

Señala este mismo autor que, para Europa, la Sentencia Klass del Tribunal Europeo de Derechos Humanos, considerando la necesidad de combatir eficazmente la amenaza del terrorismo y el creciente problema del desarrollo de las técnicas de control y vigilancia de los gobiernos, ha señalado que "las medidas de vigilancia y de control deben hallarse supeditadas a ciertos límites en una sociedad democrática "para impedir que se deslice insensiblemente hacia el totalitarismo. Ya que en otro caso se corre el riesgo de que estas medidas puedan llegar a destruir la democracia con el motivo de defenderla". Por ello, el Tribunal Europeo sentó la importante tesis de que el poder de controlar en secreto a los ciudadanos, característico del Estado-policía, "no es tolerable según el Convenio sino en la medida estrictamente necesaria para la salvaguardia de las instituciones democráticas" ${ }^{34}$.

Pero la recogida de informaciones por razones de defensa nacional o de seguridad pública constituye, en verdad, sólo un aspecto $-y$ probablemente limitado- del cúmulo de las informaciones que diariamente la Administración recoge sobre los ciudadanos.

En los últimos años se ha producido una tendencia a la informatización y establecimiento de redes informáticas en los ámbitos del Gobierno y la Administración. En España el llamado Proyecto REINA (Recursos Informáticos de la Administración) demostró que la mayor presencia de equipos informáticos "...están a disposición de los Ministerios de Hacienda e Interior" ${ }^{\prime 3}$, es decir, precisamente en aquellas dependencias gubernativas desde las cuales se justifica una mayor disposición a la vigilancia fiscal o de seguridad ciudadana. Sin perjuicio de reconocer las "innumerables ventajas" que la informatización de la función ejecutiva trae consigo, el profesor Pérez Luño, advierte que

33 Antonio-Enrique Pérez Luño. "La contaminación de las libertades en la sociedad informatizada y las funciones del Defensor del Pueblo". Anuario de Derechos Humanos, N ${ }^{\circ}$ 4. Edit. Universidad Complutense, Madrid, 1986-1987, p. 267. Las informaciones son recogidas por el autor del libro de A.F. Westin y M.A. Baker, Databanks in a Free Sociey, Quadrangle Books, New York, 1972, pp. 4 y ss. y del libro de A.F. Westin, Impact of Computers on Privacy, en Datamation, 1979, vol. 25, núm. 14, pp. 190 y ss.

34 Ibidem, p. 267.

35 Francisco Moreno Marín. Op. cit., p. 313. 
“...en este terreno quizás estemos asistiendo a un exagerado uso de los medios electrónicos, lo que, en muchas ocasiones, más que una garantía para los administrados comporta una peligrosa ingerencia en su vida privada. El fenómeno del progresivo empleo de medios electrónicos por el Ejecutivo -agrega- se halla cada vez más extendido, hasta el punto de que se hace preciso velar para que tal empleo se circunscriba al cumplimiento de las funciones que le corresponden y no se actúe en detrimento de la intimidad personal; en otras palabras: es preciso que el ejecutivo vea en la tecnología un medio, adecuado a las exigencias de nuestro tiempo, para hacer plenamente efectivos los derechos públicos subjetivos, antes que un mero aparato de control social" 36 .

En Italia, la constitución de un sistema informativo con sede en la Presidencia del Consejo de Ministros, ha sido justificada por Mauricio Italo Balla y Matelda Grassi, en la necesidad de disminuir los riesgos en la toma de decisiones, modificar los procesos de gestión y en el logro de una mayor eficacia de los servicios ${ }^{37}$. En este estudio se propone la conexión con servicios informativos externos, la creación de una base de información para la monotorización de la actividad de gobierno y, la preparación de instrumentos para la gestión automática de los archivos y de la documentación interna ${ }^{38}$.

En Chile, luego del fracaso - por razones conocidas, en la década del 70- del llamado Proyecto Cinco, que dirigía el entonces Ministro del Presidente Salvador Allende, Fernando Flores, a través del cual se buscaba generar en la Presidencia de la República un centro computacional en el cual fuera posible registrar instantáneamente información sobre las más diversas materias que interesaran al gobierno de la $\mathrm{Nación}^{39}$, el

36 Antonio-Enrique Pérez Luño. Cibernética, Informática y Derecho (Un análisis metodológico). Publicaciones del Real colegio de España, Bolonia, 1976, p. 31.

37 Crf. Mauricio Itaio Balla, Mauricio y Matelda Grassi. "La Informática Político-Jurídica como apoyo de la actividad de Gobierno". En Documentación Administrativa. Núm. 199, p. 96.

38 Ibidem, cfr., passim.

39 En la formulación de este provecto tuvo una gran influencia el profesor inglés Stafford Beer, que formaba parte de la Comisión. Para analizar el espíritu de su propuesta, revisar su libro Designing Freedom, de 1974, traducido al español como Diseñando la Libertad, Breviarios del Fondo de Culrura Económica, Madrid, 1977. Fernando Flores pasó, posteriormente, a formar parte de la dirección del "Centro Mundial para el desarrollo de los usos sociales de la micro-informática", creado a instancias del Gobierno de Miterrand, con fecha 20 de noviembre de 1980, con el objeto de contribuir desde un punto de vista cibernético al mejora- 
gobierno del Presidente Aylwin creó, bajo la dirección del Ministerio del Interior, un Grupo Interministerial Informático, encargado de interconectar en red a los distintos ministerios y servicios de la administración con las intendencias y gobernaciones regionales provinciales, así como una red que uniera a la mayor parte de los municipios del país ${ }^{40}$.

Todas estas iniciativas obedecen, sin duda, a loables objetivos de mejoramiento de la eficiencia y la eficacia de la tarea administrativa, pero es indispensable que sean sometidas a controles políticos y jurídicos igualmente eficaces, para garantizar el pluralismo informativo de los poderes del Estado y los derechos fundamentales de los ciudadanos.

En esta materia el profesor español José María Souvirón ha insistido en la conveniencia ".. de recorrer caminos de equilibrio entre el interés público y los derechos de los ciudadanos" ${ }^{\prime}$.

\section{Las consecuencias en el esquema de separación de poderes en el Estado}

Los efectos que en la práctica de la separación de los poderes del Estado puede producir la tendencia a la concentración del poder informativo del Estado, han sido descritas por André Vitalis ${ }^{42}$. En la consideración de la informática como factor de desequilibrio de los poderes del Estado, el profesor galo y miembro fundador del Centre de coordination pour la recherche el l'enseignement en informatique et société, ha mencionado dos aspectos: a) el debilitamiento de los controles parlamentarios y, lo que él denomina, b) La dépendance des collectivités locales.

miento de las estrategias de desarrollo económico de los países del tercer mundo. El primer presidente de esta Comisión fue Jean-Jacques Servan Schreiber. Cfr. la crítica que hace a esta Comisión el profesor italiano Vittorio Frosini, en op. cit.: "Informática y...", pp. 132 y 133.

40 El Grupo Interministerial Informático fue constituido mediante Decreto del Ministerio del Interior en el curso del año 1990, su primer Presidente fue el entonces Subsecretario de Desarrollo Regional y Administrativo, Gonzalo Martner Fanta y su Secretario General, el actual Subsecretario del ministerio de Obras Públicas, ingeniero Germán Quintana.

41 José María Souvirón. "En torno a la juridificación del poder informativo del Estado y el control de datos por la Administración". Revista Vasca de Administración Pública, $N^{\circ}$ 40, setiembre-diciembre 1994, p. 126. 


\section{a) El debilitamiento de los controles parlamentarios}

Para Vitalis el debilitamiento de los controles parlamentarios tiene como base, en el caso de Francia, la posición dominante que cada vez ha ido adquiriendo el Poder Ejecutivo, acompañado de la legitimación que ha alcanzado con la introducción del sistema de elección presidencial directo. Este sistema coloca al Jefe del Estado en una situación superior, que le permite controlar (y manipular) de mejor forma la administración y relegar a un papel secundario a las instancias de representación. El Parlamento quedaría así reducido al de una Cámara de registro, a un réservoir d'idées, quedando las libertades sometidas a un esquema de estrecha vigilancia que la informatización de la administración agudiza ${ }^{43}$.

Esta prevención realizada por Vitalis para el sistema político francés es perfectamente homologable a los regímenes parlamentarios del resto de Europa, donde la tendencia ha sido la de fortalecer el papel del Ejecutivo $^{44}$. Recientemente, en Italia, el movimiento de reforma constitucional parece encauzarse precisamente en este sentido, y es común escuchar la conveniencia de aplicar al caso italiano las modalidades del sistema semipresidencial francés, que supone la existencia de un Ejecutivo vigorizado.

En Latinoamérica, a su vez, el modelo presidencial ha formado parte de la tradición de los Estados desde su independencia, pese a la tendencia actual a la introducción de reformas dentro del sistema hacia esquemas parlamentarios o semipresidenciales ${ }^{45}$.

En España, la existencia de un régimen parlamentario que se ha caracterizado durante gran parte del gobierno socialista, por la concurrencia de un gobierno de mayoría absoluta, ha generado igualmente la crítica política y académica hacia las prácticas "presidencialistas" del

42 André Vitalis. Informatique, Pouvoir et Libertés. Económica, 2a. Ed., París, 1988.

43 Ibidem, cfr., p. 124.

44 Cfr. Manuel García Pelayo. "Es teóricamente posible un mundo con una ideología fija e inmutable". Entrevista publicada el 25 de junio de 1966 en el Nacional de Caracas y que forma parte de sus Obras..., op. cit., p. 3241. Respecto al régimen semipresidencial francés, Jacques Robert, ha hecho hincapié durante el curso celebrado en el Centro de Estudios Constitucionales de Madrid, durante el año académico 1994-1995, sobre el extraordinario poder ejercido por el Presidente de Francia, a su juicio, aún mayor que el correspondiente al Presidente de los Estados Unidos.

45 Cfr. Carlos M. Ayala Corao. El Régimen Presidencial en América Latina y los planteamientos para su reforma. Editorjal Jurídica venezolana, Caracas, 1992, passim. 
Gobierno, suscitándose una polémica global sobre el funcionamiento mismo del Parlamento, el papel de la oposición y el reforzamiento de los controles parlamentarios ${ }^{46}$.

Para Vitalis, el papel rector del Ejecutivo se ha visto además acrecentado, en desmedro del parlamento, por el reforzamiento de los sistemas de información en los niveles centrales de la administración, la transferencia del poder informativo entre los centros mejor equipados y más poderosos, como los ministerios de Guerra y de Finanzas, de Justicia e Interior, y por un nuevo tipo de centralización, a la que denomina les systémes d'information interadministratifs. A través de estos últimos es posible influir notablemente en los procesos de tomas de decisión, sin que esos sistemas queden afectos a un adecuado control político. Es el caso, por ejemplo, de la formación de bancos de datos sectoriales que, pese a su carácter interministerial, logran ser utilizados por ciertas dependencias ministeriales más poderosas o interesadas en su utilización ${ }^{47}$.

En un esquema tal el proceso de toma de decisiones corre el riesgo de desnaturalizarse, poniendo en tela de juicio el sentido último del sistema de gobierno representativo, que no es otro que poner freno al poder despótico ${ }^{48}$, a través de representantes "esclarecidos del pueblo

46 En palabras del profesor Lucas Verdú: "El sistema español actual de mayoría absoluta perjudica al pluralismo político, intercepta y desvirtúa el tracto procesal-electoral parlamentario. La mayoría absoluta impone cuotas de poder en el Tribunal Constitucional, en el Consejo General del Poder Judicial, en el Tribunal de Cuentas y en el Consejo de Televisión ... La libertad e independencia de los operadores jurídicos sufre en su entraña por muy honestos y virtuosos que sean sus titulares. ¿Quién puede resistir a las finanzas, a los medios oligopólicos que controlan la publicidad y a la partidocracia que manipula la dinámica electoral y parlamentaria? Cfr. Op. cit.: La Constitución en la ..., p. 112.

47 Cfr. André Viralis. Op. cit., pp. 116 a 123.

48 Como se señala en la "Encyclopédie ou Dictionaire raisoné des Sciences, des Arts et des Métiers", cuando se explica la voz "representantes": Señalaba Diderot -a quien se atribuye la redacción de este pasaje-: "Los gobiernos adquieren madurez tan sólo a través de avances lentos e imperceptibles: basados inicialmente en la fuerza no pueden mantenerse, sin embargo, sino a través de leyes justas que aseguren las propiedades y los derechos de cada ciudadano, y que lo protejan de la opresión; los hombres se ven finalmente impulsados a buscar en la equidad remedios contra sus pasiones. Si la formación de los gobiernos no hubiese sido ordinariamente la obra de la violencia y la sinrazón, se habría comprobado que no puede haber sociedad duradera si los derechos de cada uno no son puestos al abrigo del poder, que siempre desea abusar; en cualquier mano que se deposite el poder, se vuelve nefasto, si no es frenado por ciertos límites... Ningún hombre, por muy ilustrado que sea, es capaz de gobernar una nación entera sin consejos y sin apoyos; ningún estamento del Estado puede tener la capacidad o voluntad de conocer las necesidades de los demás; así el soberano imparcial debe escuchar las 
que controlen el ejercicio del poder político. En su clásico libro sobre el gobierno representativo John Stuart Mill se preguntaba sobre la verdad de aquella vieja afirmación por la cual se preconizaba "que si se encontrase un buen déspota la monarquía despótica sería la mejor forma de Gobierno". Stuart Mill rechazaba inicialmente esta idea por su imposibilidad práctica. "El hecho-decía-es que para realizar todas esas condiciones [encontrar un individuo eminente, virtuoso e inteligente, capaz de hacer buenas leyes y de dirigir la administración con acierto] hace falta un monarca que no solamente sea bueno, sino que sea capaz de verlo y examinarlo todo. Debe hallarse informado exacta y minuciosamente de cómo son dirigidas y funcionan a todas las ramas de la administración en todas las partes del reino: durante las veinticuatro horas del día, que es el plazo de que dispone el Rey como el más simple artesano, ha de otorgar a cada esfera de tan vasto campo una parte suficiente de atención y de vigilancia..." ${ }^{49}$, todas son condiciones, como puede verse, que la informática es hoy perfectamente capaz de poner a disposición de los gobernantes. El pensador inglés, sostenía sin embargo, que ni aún cuando dichas condiciones pudieran ser cumplidas era deseable un tal tipo de gobierno, porque "¿Qué clase de hombres pueden formarse bajo parecido régimen?”, se preguntaba. Sólo alguno -era su respuesta- que al cabo de cierto tiempo recayera "en la condición de un pueblo oriental" 50 , esto es, en el despotismo.

Por ello el gobierno perfecto, decía Stuart Mill es el representativo, esto es, aquél en que "la nación, o al menos una parte numerosa de ella, ejerza, por medio de diputados que nombra periódicamente, el poder supremo de inspección e intervención" ${ }^{51}$. Pero tal poder no podrá ejercerse adecuadamente, cuando: 1 . Reinen la ignorancia y la

opiniones de todos sus súbditos y está igualmente interesado en comprenderlos y en remediar sus males. Pero, para que los súbditos se expliquen ordenadamente, conviene que tengan sus representantes, es decir, ciudadanos más esclarecidos que los demás, más interesados en la cosa pública ... cuya situación les coloca en posición de sentir las necesidades del Estado, los abusos que en él se introducen y los remedios que conviene aportar". Ver, Denis Diderot y Jean Le Rond d'Alembert. Artículos políticos de la Enciclopedia, Selección, traducción y estudio preliminar de Ramón Soriano y Antonio Porras. Editorial Tecnos, Madrid, 1992, p. 178 (las negritas son nuestras).

49 John Stuart Mill. Del Gobierno representativo. Editorial Tecnos, Madrid, 1994, p. 30.

50 Ibidem, p. 32.

51 Ibidem, p. 54 (las negritas son nuestras). 
incapacidad generales del cuerpo legislativo; o, 2. Cuando la Asamblea se haya sometida a intereses que no se identifican con el bienestar general. Los cuerpos representativos -decía Stuart Mill- deben poseer y ejercer "seriamente un derecho de inspección general" ${ }^{52}$. El sistema habrá de peligrar "si la Constitución de la representación no asegura una dosis suficiente de inteligencia y de saber a la Asamblea representativa" 53 .

Pues bien, no está demás recurrir a los viejos principios para observar si tales prevenciones se cumplen en las sociedades complejas en que actualmente vivimos. ¿Es posible afirmar, que los actuales cuerpos representativos gozan de esas virtudes de "esclarecimiento" y de "inteligencia" y de "saber" que les permitan ejercer con seriedad su función fiscalizadora, cuando la función de administrar se ha transformado en inconmensurable? ${ }^{54}$

No es del todo desacertado afirmar que la configuración de contrapoderes fácticos de control de la información pueden ayudar a una práctica parlamentaria eficaz, pero contra esta idea pesa la tradición del secretismo en la realización de las funciones públicas ${ }^{55}$, que ha encontrado su desarrollo en el desenvolvimiento y posterior influencia del sistema administrativo francés y en sus reminiscencias del Ancien Régi$m e n^{56}$. Debe recordarse que la llamada doctrina del "móvil político" en los actos de la administración perduró en Francia hasta el dictado de la ley de 24 de mayo de 1872, abandonándose esta doctrina "por una nueva concepción objetivista en consonancia con los fines d'un Ëtat républicain et de droit" ${ }^{\prime 5}$.

52 Ibidem, p. 73.

53 Ibidem, p. 74.

54 Para el caso de España, señala Joan Subirats, en "Un problema de estilo. La formación de las políticas públicas en España". Centro de Estudios Constitucionales, Cuadernos y Debates No 38, Madrid 1992, p. 36, que: "A partir de 1982, y resuelta en buena parte la fase institucional-fundacional, queda claro que la decisión normativa, si bien es ratificada por el Parlamento (un Parlamento en el que se ha endurecido la disciplina de los grupos parlamentarios), viene ya "cocinada" desde la administración, y por lo tanto se produce una mayor marginación de ese escenario, teóricamente privilegiado, del procesamiento de los problemas y de sus soluciones".

55 Para Max Weber: "Toda burocracia procura incrementar esta superioridad del saber profesional por medio del secreto de sus conocimientos e intenciones. El gobierno burocrático es por su misma tendencia un gobierno que excluye la publicidad". Vid. Economía y Sociedad. Fondo de Cultura Económica, Madrid, 1993, p. 744.

56 Cfr. supra.

57 Cfr. Francisco Caamaño. El Control de Constitucionalidad de Disposiciones Reglamentarias. Centro de Estudios Constitucionales, Madrid, 1994, nota al pie, p. 91. 
Desde el punto de vista de la práctica parlamentaria la materia anterior entronca con los llamados derechos de información de la oposición parlamentaria ${ }^{58}$.

El constitucionalista alemán, Hans Peter Schneider, ha distinguido entre los derechos de información clásicos de estas minorías, los derechos de información absolutos y relativos. Los primeros pueden ser ejercidos con independencia de la decisión de la mayoría, y se traducen en los mecanismos de la interpelación, la pregunta oral y escrita y el derecho de encuesta; los segundos, en cambio, requieren de dicha decisión y se manifiestan en la solicitud de comparescencia de los miembros del gobierno o de información de ciertas decisiones adoptadas por la Cámara Federal. En ambos casos, sin embargo, el que se otorgue o no la información dependerá de la actitud que asuma el gobierno, quedando abierta la posibilidad de que este se niegue a proporcionarla. Esta situación ha llevado a que se conciba un procedimiento distinto, conocido como de la "autoinformación", por medio del cual sería posible el acceso a ciertos documentos utilizados por el gobiernos. Este derecho fue reconocido en la Constitución de Hamburgo de 1971 como "derecho de requisitoria", de acuerdo con el cual el Senado de Hamburgo se encuentra obligado a presentar los expedientes ante el parlamento regional y sus comisiones cuando hayan sido requeridos por una cuarta parte de los miembros de éste, asegurando de este modo una participación directa de la minoría en el control administrativo.

Para Schneider, sin embargo, dado que la "revisión de expedientes" no aspira a la información suministrada, sino a la autoinformación, ella debe ser entendida como participación del Parlamento en las funciones administrativas, es decir, como "coadministración parlamentaria". Este derecho encontraría sus límites en el bien común, el secreto funcionarial, la confidencialidad, la seguridad del Estado, los intereses exteriores y en la no disminución de la capacidad funcional del gobierno. Schneider considera, no obstante, este derecho como problemático dado que sus soluciones pueden llevar sea a una confusión de responsabilidades entre el Gobierno y el Parlamento o bien a una aplicación estricta del principio de la reserva gubernamental ${ }^{59}$.

58 "Un parlamento mal informado -señala Max Weber, en op. cit., p. 745- y, por tanto, sin poder, es naturalmente mejor acogido por la burocracia, siempre que tal ignorancia sea conciliable con sus propios intereses". .

59 Cfr. Hans Peter Schneider. Democracia y Constitución. Centro de Estudios Consitucionales, Madrid, 1991, pp. 169 y ss. 
Vitalis, insiste no obstante, en que el debilitamiento del control se ha hecho inevitable por la crisis de la idea de representación. En una sociedad informatizada, señala este autor, la utilidad de los intermediarios políticos parece perder, por sí misma, importancia. Esta necesidad, justificada en la época en que las comunicaciones eran lentas y limitadas y en que el poder central estaba objetivamente alejado de los ciudadanos, no tendría razón de ser en la era de la radio, la televisión, la informática y de la telemática, en que el Gobierno puede tener una relación directa con los gobernados, como asimismo informarse de mejor forma que el Parlamento, a través de los sondeos de opinión y de los media, de los deseos y aspiraciones de la población. Esta reflexión de Vitalis, parece inspirarse en las nuevas utopías que han surgido con la eclosión de las técnicas informáticas, especialmente con aquella sostenida por Yoneji Masuda de que "el sistema político de la sociedad informatizada supondrá una transmutación de la democracia parlamentaria representativa en una democracia directa participariva", en la que a través de las redes de la información, la simulación de modelos políticos y la retroalimentación de las opiniones individuales se llegue a producir un equilibrio sobre las ventajas y desventajas de determinadas decisiones ${ }^{60}$.

Por otra parte, destaca Vitalis, la dificultad del control ante la desigualdad en el "saber" entre los dos poderes del Estado, ha conducido a un empobrecimiento de los debates parlamentarios. Frente a ello, los parlamentos han tendido a munirse de medios técnicos adecuados para contrarrestar su "falta de información". Sin embargo, siendo dependientes como lo son de las fuentes informativas administradas por el gobierno y la Administración, parece ser que la informatización del sector legislativo es sólo un remedio parcial frente a esta dificultad, de escasos efectos si no se contemplan otro tipo de medidas, como la salvaguardia de la independencia de los bancos de datos que proporcionan información al sector público (por ejemplo, transfiriendo su administración a las universidades), o mediante el reconocimiento de un nuevo derecho de control sobre las principales fuentes de producción informativa en materia económica y social ${ }^{61}$. 276.

60 Cfr. Antonio-Enrique Pérez Luño. Op. cit:: “La contaminación de las ...”, pp. 274 -

61 Crf. André Vitalis. Op. cit., pp. $125-130$. 


\section{b. Las consecuencias en el ámbito territorial}

El problema anterior se plantea igualmente en el plano de la organización territorial del poder del Estado. La utilización de las técnicas informáticas han sido consideradas desde su aparición como un factor relevante en el desarrollo de políticas descentralizadoras ${ }^{62}$ y desde los años 70 puede apreciarse en Europa y los EE.UU. no sólo una ingente utilización de microordenadores por los gobiernos regionales y locales ${ }^{63}$, sino también la incorporación en sus agendas de una política de informatización de sus respectivos sectores ${ }^{64}$.

La informatización de las unidades territoriales periféricas contribuye sustancialmente a la ejecución de las políticas públicas y a un desarrollo eficiente de la gestión administrativa regional y local, puede contribuir a evitar duplicidades en la aplicación de las políticas y a formular planes de desarrollo que reúnan características de mayor certeza política y técnica que aseguren su viabilidad, así como al mejoramiento de las técnicas de diagnóstico y pronóstico de las necesidades sociales, que faciliten su ejecución.

Sin embargo, desde una perspectiva de la separación de los poderes en la esfera territorial, puede también ser un factor que incremente la relación de dependencia de las unidades territoriales al poder central. El problema presentará naturalmente mayor o menor interés dependiendo del tipo de Estado y de la forma concreta en que se materializa la vinculación Estado-Región, Estado-municipio, poder regional y poder local. El tema es especialmente sensible en materias presupuestarias, especialmente en aquellos estados en que la elaboración del presupuesto de la Nación es competencia del gobierno central y en los que la participación de las corporaciones locales es meramente residual en su elaboración. Allí, indudablemente, las políticas de descentralización del

62 Murray Laver. Los ordenadores y el cambio social, 1982, p. 23.

63 José Manuel Castells. Aproximación a la Problemática de la Informática y Administración Pública. En Jornadas Internacionales sobre Informática y Administración Pública, Colección: Administración y Autonomía del Instituto Vasco de Ad́ministración Pública. Bilbao, 1986 , pp.37.

64 Cfr. Francisco Javier Gainza. Directrices de la Política Informática del Gobierno Vasco. José Ibañez I Senserrich: "La informática en la Administración de la Generalidad de Cataluña", entre otros artículos publicados en "Jornadas Internacionales de...", Ibidem, op. cit., pp. 181 y ss. 
presupuesto y las técnicas de control y seguimiento de los programas de desarrollo o de inversión, podrán recibir un aliciente, al contar el gobierno central con los medios necesarios para supervigilar la acción de la administración autónoma o descentralizada del Estado, pero también puede no ser más que un elemento agregado a la mantención del statu-quo, en la medida que las políticas y planes territoriales son inducidas por una administración central mejor dotada desde un punto de vista técnico e instrumental ${ }^{65}$.

Indudablemente el papel directriz en materia de políticas de desarrollo e inversión corresponde por antonomasia a los órganos del gobierno central, especialmente en aquellos estados con estructura unitaria, en los que el proceso de descentralización implica que las regiones y los municipios encuadren sus planes regionales y locales dentro de la perspectiva más amplia de los grandes objetivos nacionales. Pero una práctica auténticamente descentralizadora debe considerar el respeto a las respectivas autonomías locales y el aseguramiento de un ámbito de decisión pública que no responda a criterios puramente formales. Los estados complejos no escapan a este tipo de consideraciones, y la informática puede también ser en ellos un eficaz instrumento al servicio de una suerte de desnaturalización de los respectivos ámbitos de competencia en la organización territorial del poder, con los déficits democráticos y constitucionales que ello puede comportar ${ }^{66}$.

Por cierto, el peligro a que hacemos referencia no reside únicamente en las esferas de decisión económica, sino también en los otros variados aspectos que la teoría y la práctica de la descentralización atribuyen

65 Cfr. Joan Subirats Humet. Op. cit.: "Un problema de estilo..." El autor señala que entre los recursos más importantes que posee la burocracia ( $y$ por cierto, la burocracia central) en el proceso de determinación e implementación de las políticas públicas es el "control sobre la información". Sobre ello ha dicho: "Ante todo el control sobre la información y su misma capacidad profesional. La burocracia es quien conoce mejor que está realmente sucediendo en la aplicación de los programas públicos, conoce el grado de aceptación que generan y los principales fallos en su diseño que deberían modificarse. De alguna manera pueden implícitamente intercambiar información por influencia en el proceso decisional. El tipo de información suministrada puede conducir a que ciertos tipos de decisiones se consideren inevitables... Lógicamente no tienen el monopolio ni de la información ni de la capacidad profesional, de hecho cada tema o problema que la Administración se plantea resolver genera sus propias redes de información e influencia, pero el lugar que ocupa la burocracia en el proceso de actuación de los poderes públicos confiere a esos recursos (información, expertise) un papel nada desdenable". Ver p. 49.

66 Subirats estima que en España no son más de 300 personas los auténticos protagonistas de la formulación de las políticas públicas. Ibidem, cfr., op. cit., p. 41. 
a las colectividades locales, como la gestión de las políticas medio ambientales, de salud, de educación o del fomento de la cultura. No hay materia en la cual el gobierno central no manifieste interés y es en el seno de esta tensión entre el centro y la periferia donde la eclosión informática debe estar sometida a controles eficaces que eviten las distorsiones en el funcionamiento del sistema.

Es sabido que para el gobierno central la mayor fuente de información está constituida por los datos que les son proporcionados desde estas esferas, en aspectos tan variados como el registro de los ciudadanos en materia civil y electoral o en los catastros urbanísticos, patrimoniales y de salud que son frecuentemente controlados por los municipios $^{67}$. Un conjunto de informaciones, por lo demás, que dada su cercanía a lo que puede estimarse como los intereses más vitales de los ciudadanos pueden incidir, cuando son mal utilizados, no sólo en la disminución de los poderes territoriales, sino en la vida misma de las personas, grupos o asociaciones objetos de la recolección. La técnica de la protección de datos debe proveer, por tanto, a asegurar igualmente este último ámbito de autonomía.

Desde un punto de vista organizacional, que es el que aquí nos interesa, cabe igualmente al Estado otorgar a los órganos del poder territorial los instrumentos técnicos adecuados que les permitan contrarrestar los efectos nocivos que el monopolio del "saber" en el gobierno central puede importar a los niveles decisionales autónomos constitucionalmente garantizados, de modo que la democracia local y las instancias de representación y participación ciudadana en la esfera local no se vean minimizados. Llegados a este punto, similares prevenciones a las que formuláramos en el epígrafe anterior respecto a las relaciones entre los poderes legislativo y ejecutivo, pueden ser consideradas, de manera que cabe hacer una remisión a lo que ya enunciáramos anteriormente.

\section{Tendencia a la disminución de la esfera de autonomía de los indi- viduos}

La dignidad de la persona exige reservar a ésta un ámbito de libertad libre de interferencias que coadyuve a su desarrollo autónomo en una

67 Cfr.André Vitalis. Op. cit., p. 131. 
sociedad democrática. Esta consideración de un ámbito de autonomía no sujeto a contaminaciones es una pieza clave de todo auténtico Estado democrático de Derecho.

La forma específica en que se ha producido históricamente esta separación entre el Estado y el ámbito de "atribuciones" correspondientes a los individuos, recibe explicación sociológica en el proceso de burocratización del Estado y del Derecho. Sólo "la completa despersonalización de las funciones en la burocracia y la sistematización racional del derecho -ha afirmado Max Weber ${ }^{68}$ - han conducido en principio a la mencionada separación", a una "rigurosa distinción conceptual entre un orden jurídico "objetivo" y los "derechos subjetivos" de los individuos por él (el Estado) garantizados".

En consecuencia, si el Derecho constituye una de las formas de dominación legítima en la terminología weberiana, en caso alguno la utilización de esta técnica de control social, especialmente a través de lo que Weber denomina el tipo más puro de dominación legal: la burocrática, puede impunemente transgredir esa esfera de atribuciones que el propio Estado reconoce a los individuos, al dotarlos de personalidad $^{69}$. Menos aún cuando modernamente se postula, en una concepción que indudablemente supera la teoría clásica de los derechos subjetivos que "los derechos humanos tienen que ser reconocidos como fines de la acción política"70.

La racionalidad burocrática, por otra parte, no es exclusiva del sector público, ella también despliega su actividad en los ámbitos privados, a través de las empresas y grupos de interés. Por su intermedio los ciudadanos son muchas veces sometidos a vigilancia, en conformidad a las propias exigencias de funcionamiento del Estado social o por imperativos del mercado o de la planificación de las actividades económicas. La conservación del orden público, la seguridad nacional o el mejoramiento de las condiciones de salud y educación de la población, son, entre muchos otros, fines que el Estado debe cumplir, y para cuyo cumplimiento requiere de grandes flujos de información sobre sus ciu-

68 Max Weber. Op. cit., p. 749.

69 Cfr. George Jellinek. Op. cit. "Teoria dei Diritti...", pp.63

70 Otfried Höffe. Estudios sobre teoría del Derecho y otros ensayos. Biblioteca de Ética, Filosofía del Derecho y Política-19, dirigida por Ernesto Garzón Valdés y Rodolfo Vásquez, Distribuciones Fontamara, S.A., México, D.F. 1992 (2a. ed.), p. 101 
dadanos. Las empresas, igualmente, requieren para desarrollar sus estrategias productivas realizar innumerables encuestas con el objeto de enterarse de los hábitos de consumo y de las preferencias de sus clientes. Esto no es una novedad, y más bien es una constante en el funcionamiento del Estado y las empresas, aún en etapas pre-informáticas.

Lo verdaderamente novedoso es la multiplicación geométrica de informaciones que los detentadores de bases de datos pueden obtener mediante la utilización de las nuevas técnicas de procesamiento informático, la posibilidad de cruzarlas, y de generar bases de información a través de las cuales influir de manera ilegítima en el comportamiento de las personas. Es frecuente la tentación del Estado de recabar ciertas informaciones, con el fin de adoptar medidas de tipo preventivo en materia sanitaria, educativa y policial, de un modo tal que esta actividad ha llevado a veces a clasificar a los ciudadanos en categorías de riesgo que pueden incidir en el curso futuro de sus propias vidas. No sólo la intimidad personal o familiar puede resultar, de este modo, dañada. Hay otros aspectos de la personalidad, como los que se vinculan a la esfera patrimonial, que son cada vez mas requeridos por las empresas prestatarias de servicios, para calificar a sus potenciales empleados y al conjunto mismo de sus posibles clientes. La generalización de las tarjetas de crédito y el uso de cajeros automáticos en las actividades bancarias, de tarjetas sanitarias informatizadas en el ámbito de la salud o de sistemas de compraventa electrónica son un ejemplo de estas nuevas posibilidades, frente a las cuales el individuo se encuentra frecuentemente indefenso. Ocurre, con cierta habitualidad, que la prestación de informaciones es otorgada sin que se requiera el consentimiento de los interesados, o como se sostiene actualmente, sin que ese consentimiento sea un consentimiento informado o ilustrado acerca del uso que podrá darse a esta información. La mayoría de las veces, la información se constituye en una exigencia para el acceso a cierto tipo de prestaciones o servicios, quedando muy reducido el papel de un consentimiento libre de los afectados.

No se trata evidentemente de que deba obstaculizarse esta actividad de información de las empresas o de los servicios estatales. Ellas son un componente indispensable para el buen desarrollo de sus actividades. Se trata únicamente de precaver que ellas afecten esa área indisponible de libertad de los individuos y el aseguramiento de que sus decisiones sean adoptadas con autonomía, con plena conciencia de la valoración 
del porqué se adoptan determinadas decisiones, de manera que ellas no respondan a condicionamientos heterónomos de su conducta que no están autorizados por el ordenamiento jurídico.

La regulación de la vida privada en el ordenamiento jurídico chileno

Puede sostenerse que hasta los años setenta "en nuestro país la preocupación, tanto doctrinaria como legislativa, respecto del derecho a la intimidad personal fue muy escasa, y sólo se exteriorizó a través de algunas normas constitucionales y legales de alcance muy relativo, y de dos o tres trabajos de investigación" 71 .

En efecto, la situación chilena presenta en la actualidad la paradoja de un sistema que desde el punto de vista del ordenamiento constitucional, muestra unas características que lo colocan probablemente entre las regulaciones más completas del derecho a la vida privada, no obstante carecer de coherencia y sistematicidad en su regulación legislativa.

Es cierto que la Carta fundamental vigente confiere a las personas un mecanismo de defensa rápido y eficiente, que se traduce en la posibilidad de interponer el llamado "recurso de protección" ante las cortes de apelaciones. Sin embargo, como veremos, este mecanismo adolece de ciertas limitaciones.

En el informe presentado por los profesores Pecchi y Ortiz Sepúlveda en las jornadas Iberoamericanas de Derecho Procesal, celebradas en Madrid, en el año 1985, estos dos procesalistas de la Universidad de Concepción sostenían que en el caso chileno se presenta la peculiaridad de que su legislación no refleja el estado avanzado de la normativa constitucional sobre la materia, de manera que pareciera "no existir correspondencia entre la garantía que reconoce la Constitución y la protección que entrega la ley"72.

Debo manifestar mi total acuerdo con dichos autores, y de manera muy especial en el tema que nos ocupa, porque es evidente que aún cuando los ciudadanos puedan disponer de recursos procesales muy avanzados para proteger sus derechos constitucionales, parece lógico que en ausencia de normas legales que den cobertura al conjunto de

71 Carlos Pecchi Croce y Eleodoro Ortiz Sepúlveda. “Tutela Procesal del Derecho a la Intimidad Persona en Chile", en Revista de Derecho ${ }^{\circ} 176$, Santiago, 1984, p. 7.

72 Carlos Pecchi Croce y Eleodoro Ortiz Sepúlveda. Op. cit. p. 15. 
fenómenos que un derecho tan visto como el derecho a la vida privada puede admitir, indefectiblemente, los jueces encargados de resolver los asuntos, se verán siempre limitados -a menos de realizar una interpretación que se adecúe con valentía a las proclamaciones constitucionales-, a resolver los casos, de acuerdo con los estrechos criterios de la práctica jurisprudencial ordinaria.

Desde luego no es una impropiedad la formulación de un enunciado como el anterior. Más bien se diría que, desde hace mucho tiempo, existe conciencia en los medios jurídicos chilenos de la necesidad de ampliar los criterios interpretativos de nuestros jueces a las pautas que ya son comunes y no controvertidas en otras latitudes.

Hace ya un tiempo, dos destacados juristas chilenos, en un estudio sobre la intimidad, citaban las siguientes palabras de Goldschmidt: "la intervención del legislador para orientar la jurisprudencia no es necesaria y; en mi concepto, ni siquiera recomendable en los países en que los jueces se muestran capaces de aplicar principios generales, verbigracia, el abuso del derecho. Por el contrario, ella es indispensable en aquellos en que les falte tal capacidad". El comentario escueto pero expresivo de los articulistas, ante las prudentes reflexiones del tratadista alemán, fueron las siguientes: "Estimamos que, teniendo en cuenta el apego de la jurisprudencia a los textos, la falta de vigor de los tribunales para utilizar el trabajo de la doctrina, la ninguna atención que han recibido entre nuestros tribunales los principios generales que no estén en la ley, es la última parte del pensamiento de Goldschmidt la que conviene en Chile"'?3.

En idéntico sentido, pero en un tono menos enfático, aunque sugerente, el profesor de la Universidad Católica de Valparaíso, Jorge López Santa María, refiriéndose a la dificultad existente en el ordenamiento jurídico chileno para reclamar directamente indemnización por una lesión a la intimidad, sin recurrir a las disposiciones sobre responsabilidad civil extracontractual, señala:

"La dificultad deriva de la situación de laguna legal en que se encuentra en Chile, el derecho al secreto de la vida privada. Hay una base constitucional muy importante, que ya se ha indicado.

73 Ramón Domínguez Águila y Ramón Domínguez Benavente. Op. cit. p. 37. 
Mas la implementación legal no existe. En diversos países, por lo demás, el legislador deliberadamente ha dejado a la jurisprudencia la tarea completa de perfilar el estatuto jurídico del derecho a la privacidad, rehusando el ir más allá de una declaración del principio. Los miembros de la Comisión Constituyente entendieron que éste debía ser el derrotero chileno. El tiempo dirá en definitiva, si en nuestra Patria el secreto a la vida privada adquiere contornos precisos únicamente gracias a la obra pretoriana de los tribunales o en razón de la colaboración de los poderes legislativo y judicial"74.

Ha hecho estas observaciones previas, antes de realizar una explicación más sistemática de la evolución y contenido del derecho en la vida privada en Chile, porque me parecen fundamentales para comprender la naturaleza y el grado de complejidad que representa en nuestro ordenamiento su regulación.

Paso ahora a señalar la dinámica evolutiva de su consagración jurídica.

\section{a. La protección civil de la intimidad.}

De modo semejante a lo que ha ocurrido en otras experiencias del Derecho comparado, y particularmente en aquellas que son de algún modo tributarias del modelo francés de Derecho privado, el sistema chileno de protección del derecho a la intimidad ha tenido una trayectoria relativamente paralela.

Por un lado sólo recientemente, con la Constitución de 1980, la noción adquiere una fuerza constitucional plena, al ser reconocido como un derecho autónomo dentro del ordenamiento jurídico, y por otro, en todo el largo tiempo que le precede la normativa se caracterizó, ya sea por el reconocimiento constitucional de algunos de sus elementos, como por la regulación asistemática y restringida de la legislación.

Bien es cierto, que en el aspecto civil, pudo denotar en sus comienzos un relativo grado de avance en comparación con otros ordena-

74 Jorge López Santa María. "Consideraciones sobre el derecho a la privacidad , al Secreto de la Vida Privada", en Revista de Derecho y Jurisprudencia y Gaceta de los Tribunales $n^{\circ} 79$, Santiago, 1980. 
mientos, en la medida que el Código Civil de 1857 contempló expresamente la indemnización del daño producido por una lesión del honor o el crédito de una persona, aun cuando lo hiciera por vía de excepción. Sin embargo, veremos ahora que esta situación es más aparente que real.

A este respecto, prescribe el artículo $2331^{\circ}$ del Código Civil:

"Las imputaciones injuriosas contra el honor o el crédito de una persona no dan derecho para demandar una indemnización pecuniaria, a menos de probarse daño emergente o lucro cesante, que pueda apreciarse en dinero; pero ni aún entonces tendrá lugar la indemnización pecuniaria, si se probare la verdad de la imputación".

¿Pero, qué podemos leer de esta disposición?

Primero, el hecho, ciertamente relevante, del reconocimiento atípico en un Código Civil decimonónico de un derecho subjetivo o de un interés jurídicamente protegido (el derecho al honor), que convierte a la víctima de su lesión en titular de un derecho a exigir la correspondiente reparación.

Segundo, que este derecho a obtener reparación no es extensivo a los diversos aspectos propios de la privacidad, sino que cubre únicamente la lesión del crédito o reputación de una persona. En consecuencia aspectos tales como la violación del domicilio, la intercepción de las comunicaciones y otros derechos relacionados, quedan necesariamente sujetos a un tipo de regulación diverso.

Tercero, que la disposición envuelve la paradoja de dar reconocimiento a un derecho de la personalidad, o extrapatrimonial, con las características propias de derecho autónomo, intransferible, intrasmisible e imprescriptible, pero que sin embargo su lesión está constreñida a la prueba de un daño que no tiene que ver con la lesión misma del derecho, cual es el sufrimiento o la aflicción que ha producido a la víctima, sino con el grado de merma que le ha ocasionado en su patrimonio.

Por cierto, no es de extrañar que esta contradicción se produjera en una época en que la teoría de los derechos de la personalidad no había sido todavía formulada, y más aún si razonablemente se tiene la sospecha de que el autor del Código, que residió por largos años en Ingla- 
terra, debió conocer la doctrina patrimonialista que vinculaba estos derechos al de propiedad.

En consecuencia, como es obvio, la disposición estaba dentro de lo que podríamos llamar el espíritu de la época, que sólo consagraba la protección de la persona en consideración a sus bienes, o formando parte de una institución.

Sin embargo, parece evidente que vistas así las cosas, la referencia al derecho al honor carecía de todo sentido, porque de no habérsele mencionado en la disposición, el principio de reparación hubiese igualmente operado por la vía del artículo $2314^{\circ}$ que establece la regla general para la responsabilidad civil extracontractual ${ }^{75}$.

Es decir, era igualmente menester probar cada uno de los elementos de este tipo de responsabilidad, a saber, la prueba de la culpa, la existencia del daño y la relación de causalidad.

En una segunda etapa, la jurisprudencia admitió la indemnización del daño moral, sin embargo, esta situación no obsta a que el daño deba ser acreditado por la víctima, al igual que los otros elementos de la responsabilidad civil extracontractual.

Finalmente, y siempre haciendo referencia a la legislación civil, la ley de abusos de publicidad, establece un régimen especial para la indemnización del daño. La particularidad consiste en lo siguiente: establecido el dolo o la culpa en la difusión de hechos de la vida privada, practicado por alguno de los medios de difusión descritos por la ley, el ofendido tiene derecho a obtener reparación sin necesidad de probar el daño moral ${ }^{76}$. La fijación del monto de la indemnización debe ser fijado por el juez tomando en consideración la gravedad y difusión de las informaciones y las condiciones del afectado y de su familia, así como toda otra circunstancia que parezca digna de considerarse. Esta última situación, que se aparta de la regla general de raigambre romanista, según la cual es el juez quien decide el monto de la indemnización, según reglas de equidad, ha sido criticada por parte de la doctrina por estimar que lo importante es la determinación del daño

75 Señala este artículo: "El que ha cometido un delito o cuasidelito que ha inferido daño a otro, es obligado a la indemnización; sin perjuicio de la pena que le impongan las leyes por el delito o cuasidelito".

76 Manian Alvarado. Op. cit., p. 196. 
realmente ocasionado y no la consideración de la mayor o menor fortuna del ofensor ${ }^{77}$.

Las indemnizaciones relativas al daño patrimonial indirecto deben regirse en conformidad a las reglas generales y, por tanto, habrá de acreditarse el daño.

Aclarado de esta forma el mecanismo resarcitorio de la lesión civil al derecho de la vida privada, que ha regido desde el siglo pasado en Chile, con escasas modificaciones, nos corresponde a continuación hacer una referencia general a las disposiciones legales que, de un modo u otro lo reglamentan para finalizar analizando la preceptiva constitucional, que es la que más directamente nos atañe.

Estas disposiciones son las siguientes:

a) Diversas normas de naturaleza civil y procesal: derecho de demarcación de un predio $\left(844^{\circ}\right.$ C.C. $)$, las servidumbres de luz y de vista (Arts. $875^{\circ}$ y $878^{\circ}$ del C.C.), la reserva que es obligado mantener en los juicios de nulidad de matrimonio (Art. $756^{\circ}$ del C.P.C., la reserva de los procesos de legitimación adoptiva (Art. $11^{\circ}$ de la Ley $\left.\mathrm{N}^{\circ} 16.346\right)$, la reserva de algunas piezas de un expediente judicial (Art. $34^{\circ}$ del C.P.C.).

b) Las normas sobre secreto bancario.

c) Las disposiciones penales que tipifican los delitos de allanamiento de morada (Arts. $144^{\circ}$ y $155^{\circ}$ del C.P.), violación de la correspondencia (Art. $146^{\circ}$ del C.P.), el delito de violación de secretos (Art. $247^{\circ}$ C.P.), y los delitos de injuria y de calumnia, entre otros.

d) La Ley $\mathrm{N}^{\circ} 16.643$ sobre abusos de publicidad.

e) Una serie de normas destinadas a mantener la privacidad de las informaciones en diversas esferas de la actividad, como las que se refieren al secreto estadístico, el secreto tributario (Art. $35^{\circ}$ del C.T.), etc.

\section{b. La preceptiva constitucional}

Hemos dicho que el derecho a la vida privada, en cuanto tal, no viene a ser reconocido sino a partir de la Constitución de 1980.

77 Ramón Domínguez Águila y Ramón Domínguez Benavente, en op. cit., passim. 
La disposición que lo regula es el artículo 19.4 de la Constitución, $y$ lo hace en los siguientes términos:

"Artículo $19^{\circ}$.- La Constitución asegura a todas las personas:.. 4.- El respeto y protección a la vida privada y pública y a la honra de la persona y de su familia.

La infracción de este precepto, cometida a través de un medio de comunicación social, y que consistiere en la imputación de un hecho o acto falso, o que cause injustificadamente daño o descrédito a una persona o a su familia, será constitutiva de delito y tendrá la sanción que determine la ley. Con todo, el medio de comunicación social podrá excepcionarse probando ante el Tribunal correspondiente la verdad de la imputación, a menos que ella constituya, por sí misma el delito de injurias a particulares. Además, los propietarios, editores, directores y administradores del medio de comunicación social respectivo serán solidariamente responsables de las indemnizaciones que procedan".

Normalmente, también, se estima como parte de su normativa, el artículo $19^{\circ} \mathrm{N}^{\circ} 5$ de la Constitución, que garantiza la inviolabilidad del domicilio, prescribiendo que la Constitución asegura: " 5.- La inviolabilidad del hogar y de toda forma de comunicación privada. El hogar sólo puede allanarse y las comunicaciones y documentos privados interceptarse, abrirse o registrarse en los casos y formas determinados por la ley".

Las constituciones anteriores, desde la propia Constitución de 1833 y la Constitución de 1925, establecieron explícitamente la garantía de la inviolabilidad del domicilio y de la correspondencia.

En la Constitución de 1833 se consideraban estos derechos en los artículos $137^{\circ}$ y $138^{\circ}$, formando parte del Capítulo IX de la Constitución titulado "De las garantías de la seguridad y propiedad".

En relación a la inviolabilidad del domicilio, decía la Constitución de 1833, la de más dilatada aplicación en Chile, dado que rigió casi en su integridad hasta la Carta de 1925, que (Art. 137\%), "La casa de toda persona que habite el territorio chileno es un asilo inviolable, y sólo puede ser allanada por un motivo especial determinado por la ley, y en virtud de orden de autoridad competente". 
Es interesante destacar que un tratadista de dicha Constitución, Alcibíades Roldán, ya consideraba que "La morada particular de toda persona constituye una extensión de sí misma, el centro donde convergen los afectos de que aquella es capaz" ${ }^{17}$.

Los principales problemas que representó esta disposición, según comenta el iuspublicista chileno Jorge Huneeus, en su clásica obra sobre la Constitución de 1833, publicada en 1891, hacía referencia a que hasta el año 1880 no se había aún establecido con claridad cuáles eran los "motivos especiales" que justificaban el allanamiento, ni la "autoridad competente" encargada de decretarlo.

Señala Huneeus, que los debates sobre esta materia, tanto en el Senado como en la Cámara de Diputados habían sido numerosos en el correr del siglo, e incluso en los años 1843 y 1864, respectivamente, habían sido presentados sendos proyectos para regularla por los eminentes juristas Mariano Egaña y José Victorino Lastarria, sin que ellos llegaran a prosperar ${ }^{79}$.

En general, puede decirse que la mayor parte de la doctrina (Jovino Novoa y el propio Huneeus), sostenían que esta facultad correspondía exclusivamente al juez. Sin embargo, hasta el año 1885 , la situación era incierta puesto que la ley entregaba esta facultad, en ciertos casos, a los gobernadores de las provincias.

Desde el 22 de diciembre de 1885, fecha en que se dictó la Ley de Régimen Interior, hasta la dación del Código de Procedimiento Penal en 1894, que reglamentó definitivamente la situación, rigió la normativa de dicha ley y aquella propia de la Ley de Municipalidades de 22 de diciembre de 1891, pese a lo cual persistió un vacío legal en la materia que sólo fue llenado por el mencionado Código.

"La ley de Régimen Interior estableció, desde luego -como refiere Alcibíades Roldán, el principio de que corresponde a la autoridad judicial dictar los decretos de allanamiento" (p. 175). Los gobernadores sólo podían expedirlos en casos excepcionales, señalados por las leyes, como situaciones de epidemia o inundaciones, delito flagrante o contrabando, o, finalmente, en casos de desórdenes o excesos en estableci-

78 Alcibiades Roldán. Op. cit., p. 174.

79 Jorge Huneeus. La Constitución ante el Congreso, 2a edición, Tomo II, Imprenta Cervantes, Santiago, 1891, p. 234. 
mientos destinados a espectáculos o a la recreación de la población, siempre, en estos últimos casos, por medio de una orden escrita de gobernador.

La Ley de Municipalidades, por su parte, confirió "al primer alcalde la facultad de decretar visitas domiciliarias de inspección para fines de salubridad, seguridad y orden públicos, y expedir decretos de arresto y allanamiento en los casos, modo y forma prescritos para los intendentes y gobernadores" (Roldán, p. 175).

El Código de Procedimiento Penal, si bien habría de completar esta normativa, dejó vigentes las facultades conferidas a otras autoridades que la judicial por la Ley de Régimen Interior y de Municipalidades, pero estableció que una vez que el juez hubiese entrado a conocer de un asunto, dichas autoridades debían abstenerse de ejercerlas (Roldán, p. 176) (actual artículo $183^{\circ}$ del C.P.P.).

Por su parte, y en este mismo orden de ideas, el Código Penal de 1874 , artículo $155^{\circ}$, aún vigente, estableció penas para el empleado público que allanare un templo o casa, "abusando de su oficio", y el artículo $144^{\circ}$ del mismo cuerpo legal, estableció las penas correspondientes a todo el que "entrare en morada ajena contra la voluntad de su morador".

En lo que respecta a la inviolabilidad de la correspondencia, establecía la Constitución (Artículo 138 ) que "La correspondencia epistolar es inviolable. No podrán abrirse, ni interceptarse, ni registrarse los papeles o efectos, sino en los casos expresamente señalados por la ley".

A juicio de Huneeus, esta garantía es absoluta y no admite "otras limitaciones que las que el Derecho Internacional autoriza en caso de guerra exterior". Más adelante, expresa: "Esta excepción única de la regla consignada en la primera parte del artículo $138^{\circ}$ se rige, no por nuestra Constitución, sino por el Derecho de Gentes".

Reformada la Constitución en el año 1874, la creencia de que en los casos de estado de sitio o conmoción interior esta garantía quedaba exenta para el Ejecutivo, "no sería sostenible en sentido alguno" ${ }^{\circ 0}$.

Sin embargo, como el mismo Huneeus refiere (p. 348), existían leyes especiales que autorizaban abrir, interceptar o registrar papeles y efectos. Estas leyes eran: las leyes de aduana, las disposiciones del Có-

80 Jorge Hunneus,. Op. cit., p. 347. 
digo de comercio que ordenan la exhibición de libros de los comerciantes, y los artículos $146^{\circ}, 155^{\circ}$ y $156^{\circ}$ del Código Penal, que tipifican los delitos cometidos a este respecto por los empleados públicos, los empleados del servicio de correos y los particulares.

La reserva de la correspondencia telegráfica fue establecida a través de un Reglamento dictado por el gobierno el 31 de enero de 1872 (Roldán, 177).

Asimismo, es interesante también destacar que ha constituido una constante del derecho chileno, en los dos últimos siglos, el regular aspectos que podrían ser considerados como integrantes del concepto de vida privada, a través de las leyes de abuso de la publicidad.

Ya hemos señalado antes, cómo, en el aspecto civil, la ley vigente en la materia, establece una particular manera de reparar los perjuicios cuando se lesionan intereses provenientes de la esfera de la intimidad. Pues bien, en el marco de la Constitución de 1833, la Ley de 17 de setiembre de 1872 califica como abusos de la libertad de imprenta, entre otros, " $2^{\circ}$ Los escritos en que de cualquier modo se tienda a menoscabar el crédito o buen concepto de un empleado público o la confianza que en él tiene la sociedad; $y, 3^{\circ}$ Aquellos en que se tienda al mismo fin respecto de las personas particulares" (citado por Roldán, p. 312$)^{81}$.

81 Por último, para concluir nuestra reflexión sobre el contenido de la privacidad bajo la vigencia de la Constitución de 1833 , es atinente señalar que los derechos y garantías consagrados por ella, quedaban sujetos, como era práctica universal, a su regulación por medio de las leyes y reglamentos respectivos. No obstante, la Constitución previó dos mecanismos singularmente relevantes para la protección de los derechos, uno, el Hábeas Corpus, conocido también en esa época como "recurso de protección", y las facultades que se otorgaban a la Comisión Conservadora durante el receso de la legislatura.

El recurso de protección o Hábeas Corpus era consagrado por la propia Constitución, artículo $134^{\circ}$, en los siguientes términos:

"Art. $134^{\circ}$. Todo individuo que se hallare preso o detenido ilegalmente por haberse faltado a lo dispuesto en los artículos $126^{\circ}, 128^{\circ}, 129^{\circ}$ y $130^{\circ}$ podrá ocurrir por sí o por cualquiera a su nombre a la magistratura que señale la ley, reclamando que se guarden las formas legales. Esta magistratura decretará que el reo sea traído a su presencia y su decreto será precisamente obedecido por todos los encargados de las cárceles, o lugares de detención. Instruida de los antecedentes, hará que se reparen los defectos legales y pondrá al reo a disposición del juez competente, procediendo en todo breve y sumariamente, corrigiendo por sí o dando cuenta a quien corresponda corregir los abusos".

El Recurso, concebido exclusivamente para la protección de la libertad personal y, por lo tanto, no tan amplio como para cubrir la violación de otras garantías, debía ser interpuesto ante las Cortes de Apelaciones, las que debían fallarlo en el plazo de 24 horas. El Ministerio Público, 
La Constitución de 1925, siguió un criterio semejante a la Constitución anterior al regular los derechos tradicionalmente considerados como pertenecientes a la esfera de la intimidad.

En efecto, en su Capítulo III sobre "Garantías Constitucionales" consagró en su artículo $10^{\circ}$ números 12 y 13 , los derechos a la inviolabilidad del hogar y la inviolabilidad de la correspondencia. Para ello utilizó la redacción que sigue:

\author{
"Artículo $10^{\circ}$. La Constitución asegura a todos los habitantes \\ de la República: \\ 12. La inviolabilidad del hogar. \\ La casa de toda persona que habite el territorio chileno sólo \\ puede ser allanada por un motivo especial determinado por la \\ ley, y en virtud de orden de autoridad competente".
}

\footnotetext{
una vez detectada la falta debía deducir querella contra los responsables de la infracción. Me parece de interés consignar la existencia de este recurso en la Carta constitucional de 1833 , siguiendo la tradición de la Constitución de 1822 que ya lo había consagrado en el artículo $166^{\circ}, 7^{\mathrm{a}}$, por cuanto, a esa época ningún país americano lo había incorporado a su legislación positiva. El Código Penal del Imperio del Brasil lo positivizó en $1830-8$ años después que la Carta del 22-, por lo que dicho texto fundamental chileno parece ser el primero en constitucionalizar la institución. Posteriormente, como se sabe, México incorpora a su derecho positivo el Amparo en 1841 y en la Constitución de Yucatán, pero a nivel federal sólo lo hace en 1857". Desde luego el Recurso de Protección consagrado por las constituciones de 1822 y 1833 seguía más de cerca la institución inglesa del Hábeas Corpus y no revistió las características amplias del recurso mexicano.

En cuanto a la Comisión conservadora, esta institución, ya consagrada en la Constitución de 1828 como "Corte de Representantes", "sin duda fue tomada de la Constitución española de 1812, donde llevaba el nombre de diputación permanente" (Roldán, p. 368) tenía la particularidad de que uno de sus objetos fundamentales era la protección de las libertades públicas. Respecto a estas facultades escribe Alcibíades Roldán, (p. 370):

"En el ejercicio de las facultades de supervigilancia, (la Comisión) vela por el cumplimiento de las Constitución y de las leyes, y presta protección a las garantías individuales. Para estos objetos, puede dirigir al Presidente de la República las representaciones que estime conducentes y reiterarlas por segunda vez, si no hubieren bastado las primeras. Nótese que, si se trata de violación de las garantías individuales, estas representaciones no pueden ser motivadas sino por abusos o atentados cometidos por autoridades subordinadas al Presidente, es decit, por agentes del Ejecutivo, porque si las irregularidades son cometidas por autoridades independientes de este poder, como los tribunales de justicia, serían del todo improcedentes. En caso que el Presidente no adopte las medidas que estén dentro de sus facultades para poner término al abuso y castigar al funcionario culpable, se entiende que en unión con el respectivo Ministro asume toda la responsabilidad de los actos ejecutados por la autoridad subalterna".
} 
Siendo su redacción muy semejante a la de la Constitución anterior, incorpora un término desconocido anteriormente, la noción de "hogar", que a juicio de la doctrina permite la ampliación de esta disposición a "los recintos privados en que tiene lugar cualquier especie de actividad humana" 82 .

En el mismo sentido ha expresado don Raimundo Del Río, que "se entiende por hogar, casa o morada el recinto de las habitaciones y sus dependencias, en que una persona vive o ejerce sus actividades o trabajo; y también los recintos cerrados que tenga bajo su control a cualquier título, aunque no concurran las circunstancias de vida o actividad dentro de ellos. No se estima que lo es lo que queda fuera de la construcción y sus dependencias, como una chacra o un potrero, porque lo que el legislador ha querido proteger en este caso es el atropello contra el hogar, casa o morada y no el atropello contra la propiedad" ${ }^{33}$.

En cuanto a la legislación complementaria, la legislación penal aplicable es aquella que mencionáramos al tratar de la Constitución del 33, es decir los artículos $144^{\circ}$ y $145^{\circ}$ del Código Penal.

Sentencias de las cortes de apelaciones de Concepción y Santiago han declarado que para que exista el delito tipificado por el artículo $144^{\circ}$ del Código Penal, "es necesario que la entrada en morada ajena sea contra la voluntad de su morador y no sin su permiso" ${ }^{44}$.

$\mathrm{El}$ artículo $13^{\circ}$ de dicha Constitución estableció de igual modo, la garantía a todos los habitantes de la República de "La inviolabilidad de la correspondencia epistolar y telegráfica. No podrán abrirse, ni interceptarse, ni registrarse los papeles o efectos públicos, sino en los casos expresamente señalados por la ley".

Nuevamente la redacción de la disposición es muy semejante a la de la Carta de 1833, solo que eleva a rango constitucional la violación de la correspondencia telegráfica. Pese a que, como señala Enrique Evans, de la nueva redacción pareciera desprenderse que solo se protegen "los efectos públicos", como podrían ser los instrumentos financieros o crediticios emitidos o garantizados por el Estado, "se acepta que abarca

82 Enrique Evans de la Cuadra. Relación de la Constitución Política de la República de Chile, Editorial Jurídica de Chile, Santiago, 1971, p. 192.

83 Raimundo Del Río C. Elementos de Derecho Penal, p. 352. Citado por Carlos Andrade Geywitz, en Elementos de Derecho Constitucional Chileno, Segunda Edición, Editorial Jurídica de Chile, Santiago, 1971, p. 192.

84 Carlos Andrade Geywitz. Op. Cit, p. 193. 
todo tipo de documentación personal" ${ }^{85}$. Así, por otra parte, fluye de las propias actas oficiales de la Constitución ${ }^{86}$.

La legislación penal castiga al que abra o registre la correspondencia o los papeles de otros sin su voluntad (Art. $146^{\circ}$ C.P.), ampliando o restringiendo la pena según si su contenido ha sido divulgado o se ha obtenido provecho de él. También, como hemos visto antes, existen sanciones especiales para los empleados públicos o funcionarios de los servicios de correos o telégrafos.

Existen, sin embargo, varias disposiciones que hacen excepción a estas normas, las que se encuentran contenidas, a modo ejemplar, en el propio Código Penal, o en otros cuerpos legales, como la Ley de Quiebras, el Código de Comercio o el Código de Procedimiento Penal.

Por su parte, otras excepciones fueron establecidas por la Ley $\mathrm{N}^{\circ}$ 12.927, de Seguridad Interior del Estado y el Decreto con Fuerza de Ley $\mathrm{N}^{\circ} 171$, Ley Orgánica de los Servicios de Correos y Telégrafos.

Un proyecto de reforma de la Constitución, aprobado en el año 1950 por la Cámara de Diputados, intentó ampliar esta protección a las comunicaciones radiales y telefónicas, tratando de poner al día la normativa constitucional con textos constitucionales recientemente vigentes en esa época, como el artículo $15^{\circ}$ de la Constitución italiana de 1947 o el artículo $10^{\circ}$ de la Ley Fundamental de Bonn, de 1949, que la establecían. Este proyecto, sin embargo, no prosperó.

No obstante, a esta situación ya se refería la Ley de Seguridad Interior del Estado. Al respecto ha señalado el profesor Andrade Geywitz.

"La Ley de Seguridad Interior del Estado, en su artículo $9^{\circ}$, se refiere a la "censura" de las comunicaciones telefónicas o radiales. En realidad es más propio hablar de un "control" en las comunicaciones telefónicas o radiales, pues las conversaciones telefónicas son escuchadas por los funcionarios encargados de controlar las actividades de las personas que los gobiernos consideran peligrosos para su estabilidad o captadas en máquinas grabadoras $\mathrm{y}$, las transmisiones radiales -especialmente la difusión de discursos políticos, de crítica a la gestión del Gobierno o de sus

85 Enrique Evans de la Cuadra, Op. cit., p. 38.

86 Carlos Andrade Geywitz. Op. cit., p. 193. 
personeros- impedidos de ser captados, por medio de procedimientos técnicos, de "interferencias, etc." (p. 198).

Como puede observarse, aspectos de la privacidad, considerados en otras legislaciones, han sido en el correr de los últimos siglos los grandes olvidados del ordenamiento jurídico chileno. Materias tales como la protección del nombre, del honor o de la imagen solo ha sido posible cubrirlas a través de las disposiciones especiales que las regulan en las leyes civiles o penales. Esta situación tiene la desventaja propia de una legislación inorgánica, que no considera de una manera global los aspectos propios de la privacidad, dado que continúan vigentes para situaciones enteramente nuevas y que requieren de regulación especial, medios de protección que se ajustan a modelos tradicionales pensados para épocas en que los adelantos técnicos no constituían peligros inminentes para la intimidad. No postulo, indudablemente, la idea de que el reconocimiento unitario sea la mejor forma de garantizar los derechos de las personas. Muy por el contrario, pienso que la configuración de cuerpos normativos independientes pueden ayudar mucho más a la detección de las situaciones nuevas que pueden implicar una lesión a las libertades de las personas, y de este modo establecer, también, nuevas y mejores garantías de los derechos. Es esa fundamentalmente, en todo tiempo, la misión del Derecho.

En la realidad actual, y no obstante la norma del artículo 19.4 de la Constitución vigente, parece ser prioritaria, por tanto, una mayor atención doctrinal a la privacidad, que como se ha visto en otros ordenamientos, hace imprescindible un enfoque más amplio, de Derecho público, para establecer medios de reparación que verdaderamente se adecúen a la naturaleza de las lesiones que los derechos de la esfera de la intimidad pueden verdaderamente sufrir.

Por otro lado, mientras en otros países la jurisprudencia ha ido abriendo espacio a nuevos derechos que se adscriben a normas y principios constitucionales específicos, la tendencia de los tribunales chilenos continúa siendo la de un apego estricto a la letra de la ley, por la que la actividad del legislador se hace doblemente necesaria.

Si es cierto que en Francia, por ejemplo, con cuyo sistema tanto sintoniza nuestro sistema constitucional y legal, no se ha llegado a constitucionalizar el derecho a la vida privada, ni se ha establecido una garantía de los derechos tan amplia como la que en nuestro sistema 
representa el Recurso de Protección, no lo es menos que la jurisprudencia de sus tribunales ha llegado a producir avances insospechados y difícilmente asimilables en nuestro sistema, dada su actual conformación. Por esta razón es que el profesor López Santa María ha podido manifestar su admiración por los avances de esta jurisprudencia, frente a la cual nuestro sistema permanece irremediablemente lejano. De manera muy temprana, la jurisprudencia de ese país abandonó la idea de la reparación de las lesiones a la privacidad por la vía de la responsabilidad civil extracontractual, limitándose a comprobar la existencia de un atentado al patrimonio moral ajeno. Además, "protegió a las víctimas, consagrando en su beneficio derechos subjetivos particulares: el derecho al secreto de las cartas confidenciales y el derecho de la persona sobre su imagen ... condujo a la consagración de un derecho de general amplitud; el derecho al respeto de la vida privada reconocido por diversas sentencias y después confirmado por la ley de julio de 1970, en el artículo $9^{\circ}$, inciso primero, del Código Civil" (López, p.70).

La situación descrita por López Santa María no es distinta, como hemos señalado, a la del Derecho de los EE.UU., donde el desarrollo del concepto de privacy ha llegado a configurar una verdadera nueva rama del Derecho.

En Italia, por su parte, desde una sentencia de 20 de abril de 1963 , la Corte de Casación ha llegado a considerar que la divulgación de noticias sobre la vida privada, viola el "derecho absoluto de la personalidad, entendido como derecho erga omnes a la libertad de autodeterminación de la personalidad", asimilando el derecho único de la personalidad con la noción de "derecho de libertad de autodeterminación" (López, p. 72).

En Alemania, igualmente, es de sobra conocida la labor desplegada por la jurisprudencia del Tribunal Federal Constirucional en torno al concepto de "libre desarrollo de la personalidad". Precisamente a su trasluz ha podido ser configurado el derecho de autodeterminación informativa, como esperamos que ocurra también en España una vez que el Tribunal Constitucional resuelva los recursos de inconstitucionalidad pendientes sobre la materia.

En España misma la regulación del artículo 18.4 de la Constitución y la existencia de una profusión de normas protectoras de los derechos fundamentales, muestra un grado de avance verdaderamente notable en la protección de estos derechos, que va acompañado de una gran actividad jurisprudencial y doctrinaria. 
Debemos lamentar, en cambio, que la situación en nuestro país no sea esa. Pese a que las experiencias recientes de violación sistemática de los derechos fundamentales ha debido hacernos tomar debida nota de la importancia que los estudios doctrinarios y el desarrollo jurisprudencial tiene para configurar un sistema eficaz de protección de los derechos de las personas, las particularidades de nuestro sistema constitucional de compromiso, parecen mantenernos anclados en el rígido marco de una Constitución que no admite demasiados márgenes de maniobra. El recurso de protección permanece restringido sólo a un conjunto bien determinado de derechos, y durante demasiado tiempo la jurisprudencia de la Corte Suprema lo asoció casi únicamente a la protección del derecho de propiedad.

Réstanos sólo por señalar que estas observaciones no implican en modo alguno desconocer la importancia que en nuestro medio reviste el recurso de protección y el reconocimiento del derecho a la vida privada, al que aquél es aplicable, pese a la escasa actividad judicial que hasta el momento se ha producido a su respecto.

Indudablemente sus consecuencias pueden ser insospechadas, tanto porque bajo sus auspicios pueden regularse una infinidad de situaciones no resueltas por la legislación, cuanto porque, a diferencia de otros sistemas de Derecho comparado, el acceso a la reparación inmediata de situaciones lesivas es en Chile, amplia y perfectamente posible, aplicándose correctamente los instrumentos que el constituyente ha puesto en manos de los operadores jurídicos. Falta entonces voluntad, tenacidad y hasta, porqué no decirlo, valentía, para configurar un sistema de protección que asegure a los ciudadanos la eficacia plena de sus derechos. Falta también que la formulación ideológica del sistema constitucional sea reinterpretada, a través de una transformación cada vez más democrática de la sociedad, que asiente de una vez por todas los zigzagueantes avatares de una transición no consolidada. Por lo demás, los avances económicos recientes, en la medida que se vean acompañados de un concepto más solidario que haga retomar el objetivo de una sociedad justa, habrán de constituir elementos importantes para el logro de estas metas.

Contenidos y relaciones del derecho a la intimidad con otros derechos en la legislación chilena. 


\section{Derecho a la intimidad e inviolabilidad del domicilio.}

La Comisión de Estudios de la Nueva Constitución estimó que el derecho a la vida privada y la inviolabilidad del hogar, constituyen "dos garantías distintas" ${ }^{77}$ porque, como manifestara el profesor Ovalle: "La protección de la intimidad de la vida privada es una protección a algo que tiene cierta calidad de abstracto, que es la forma cómo cada uno mira sus propias relaciones con las personas queridas, con su familia, y como ve su propia honra. En cambio, la protección del hogar y la correspondencia es protección de cosas concretas, que se expresan de diversas maneras y que se traducen en hechos materiales"

Esta última situación fue analizada por la Comisión de Estudios Constitucionales en la sesión celebrada con fecha 12 de junio de 1975. Después de una larga discusión se estimó que era conveniente seguir utilizando la expresión tradicional del derecho constitucional chileno, "inviolabilidad del hogar", por ser ésta comprensiva no sólo de la casa habitación donde se duerme o vive, sino también de los recintos privados en que se ejerce una actividad. Ello a diferencia de la expresión "domicilio", que tiene un sentido jurisdiccional y, por tanto, más restrictivo. En definitiva, y a propuesta del Sr. Jorge Ovalle, la Comisión acordó que por hogar debía entenderse "el recinto de las habitaciones y sus dependencias en que una persona vive o ejerce sus actividades de trabajo, y también los recintos privados que tenga bajo su control a cualquier título, aunque no concurran las circunstancias de vida o actividad dentro de ella" ${ }^{89}$ esto es, lo que doctrina llama un "domicilio simulado" 90 .

En el ordenamiento chileno no queda claro que las personas jurídicas puedan ser titulares del derecho a la inviolabilidad del hogar, como ha sido reconocido por el Tribunal Constitucional español, ni tampoco se han establecido en el artículo $19^{\circ} \mathrm{N}^{\circ} 5$ de la Constitución chilena, límites más específicos a la libertad del legislador. Más bien se ha en-

87 Actas Oficiales de la Comisión Constituyente, sesión 129a, p. 5 (expresión utilizada por el constitucionalista Jorge Ovalle).

88 Ibidem, p. 5.

89 Es decir, se adopta la definición formulada para el "hogar" por el penalista chileno Raimundo Del Río, en su obra Elementos de Derecho Penal, a la que nos hemos referido stipra.

90 Fernando López Ramón. Op. cit., p. 50. 
tregado a éste un mandato general para establecer dichos límites. En general, parte de la discusión de la Comisión Constitucional discurrió sobre la base propuesta por el Sr. Jaime Guzmán, en el sentido de diferenciar entre la inviolabilidad del hogar, más relacionada con la esfera material de intimidad de una persona y la inviolabilidad de todo recinto privado, asociado a la garantía del respeto a la propiedad. Esta distinción, sin embargo, no fue aceptada por la comisión, y pese a que pasó por alto la consideración del domicilio de las personas jurídicas, se estimó que la expresión hogar, como hemos manifestado antes comprende la de todo recinto cerrado, aun cuando en él no concurran "circunstancias de vida o actividad", es decir, independientemente, a nuestro juicio, de que en dichos recintos se expresen circunstancias de la vida privada propias de las personas físicas.

El artículo 18.2 de la Constitución española utilizó, en cambio, un criterio más garantista, al señalar la necesidad del consentimiento del titular o una resolución judicial para proceder a la entrada o registro de un domicilio, salvo que en él se esté cometiendo un delito flagrante. ${ }^{91}$

En este sentido, coincido con la opinión manifestada por el profesor Jorge Ovalle en la Comisión de Estudios de la actual Constitución chilena, al abogar por la utilización del concepto de domicilio, de mayor precisión jurídica y comprensivo de todo tipo de domicilio, incluido a nuestro parecer, el que la legislación civil atribuye a las personas jurídicas. El uso de esta terminología, hubiese evitado las ambigüedades interpretativas que necesariamente surgen del precepto constitucional chileno, y no habría sido contradictorio con las normas legales que también extienden esta protección a las personas jurídicas ${ }^{22}$.

\section{Derecho a la intimidad y derecho a la propia imagen.}

En la doctrina chilena hay quien sostiene que el derecho a la propia imagen es un derecho "específico e independiente de otros derechos de

91 En el caso chileno, en cambio, la legislación penal establece que para que se configure el delito de violación de domicilio debe procederse "contra la voluntad" del morador, no siendo suficiente obrar sin su consentimiento (artículo $144^{\circ}$ del Código Penal).

92 El Código de Procedimiento Penal Chileno, en sus artículos $156^{\circ}$ a $183^{\circ}$, limita la entrada y registro en lugares cerrados, sean éstos públicos o privados, a una resolución judicial previa y, en ciertos casos, fundada. 
la personalidad, al que las exigencias y las formas de vida social moderna han debido limitar, en aras de la libertad general y de una convivencia más amplia y fácil, transformándolo únicamente en un derecho negativo, consistente en la posibilidad de su titular de manifestar su rechazo expreso a que su imagen sea conservada por otro" ${ }^{3}$.

En el derecho francés se ha tendido a vincular el derecho a la propia imagen con el derecho a la intimidad, a lo que se denomina "la apariencia de la personalidad". De este modo J. Robert, lo define como "el derecho de la persona a ser percibida por terceros con la apariencia que ella ha escogido" 94 , confundiéndosele a veces con la protección al nom$b^{95}{ }^{95}$. Un tratamiento parecido del tema se da en el Derecho italiano ${ }^{96}$.

Esta misma confusión se plantea en el Derecho chileno, donde se entiende por algunos que la imagen "comprende tanto las fotografías ... tomadas sin autorización, y publicitadas ... como también el uso de un nombre de una persona (v. gr. un profesional) en una teleserie, y que aparece como malvado o deshonesto precisamente en el mismo ámbito profesional en el que se desempeña aquella" ${ }^{\prime 7}$. Así ha sido estimado, además, por los tribunales chilenos ${ }^{98}$.

\section{Derecho a la intimidad y derecho al secreto profesional.}

En Chile se entiende que la garantía del secreto profesional encuentra cobijo dentro de la norma del artículo $19^{\circ} \mathrm{N}^{\circ} 5$ de la Constitución, que consagra el derecho a la privacidad de las comunicaciones y documentos privados ${ }^{99}$. Por otra parte, el artículo $349^{\circ}$ del Código de Proce-

93 Eduardo Novoa Monreal. Op. cit., "Derecho a la Vida Privada...", p. 71.

94 Jacques Robert. Op. cit. p. 370.

95 Avis de la CNIL n ${ }^{\circ} 81-68$ de 9 de junio de 1981, en el cual considera que no es lícito dar a conocer el antiguo nombre de una persona que se lo ha cambiado. En España la STS 26/1/90, resolvió en idéntico sentido admitiendo una demanda por la utilización del apelativo "Marqués de Bradomín" para designar una marca de vino.

96 De Cupis. I Diritti della Personalitá. Milano, 1982, $2^{\text {a }}$ edición, p. 283

97 Eduardo Soto Kloss. En Comentario a la Sentencia Böhme Bascuñan, de la Corte de Apelaciones de Santiago.

98 Caso Walker Cerda, RDJ t. 81 (1984) 2.5, 238-240.

99 Cfr. Alejandro Vergara Blanco. El Secreto Bancario. Sobre su Fundamento, Legislación y Jurisprudencia. Editorial Jurídica de Chile, Santiago 1990, p. 101. Si bien este autor 
dimiento Civil, señala que "podrá decretarse, a solicitud de parte, la exhibición de instrumentos que existan en poder de la otra parte o de un tercero con tal que tengan relación directa con la cuestión debatida y no revistan el carácter de secretos o confidenciales". En materia penal, los artículos $246^{\circ}$ y $247^{\circ}$ del Código del ramo sancionan tanto al empleado público que revelare los secretos de que tenga conocimiento por razón de su oficio o entregare indebidamente papeles o copia de papeles que tenga a su cargo y no deban ser publicados, como al empleado público que, sabiendo por razón de su cargo los secretos de un particular, los descubriere con perjuicio de peste. Del mismo modo, el inciso segundo del artículo $247^{\circ}$ penaliza "a los que ejerciendo alguna de las profesiones que requieren título, revelen los secretos que por razón de ella se les hubiere confiado".

Para diferenciar el derecho al secreto profesional del secreto bancario, al que a veces se ve como una especie del primero, la Corte de Apelaciones de Santiago en la sentencia de 27 de enero de 1981, recaída en el recurso de protección interpuesto por el Banco de Santiago contra el Servicio de Impuestos Internos, matizó las características de ambas figuras jurídicas. Consideró la sentencia que "la expresión «secreto profesional” es de carácter restrictivo y se aplica sólo a aquellos profesionales que como los abogados, notarios, médicos y confesores, son depositarios de secretos en virtud de la confianza que su título inspira" y, por tanto, no a los gerentes de bancos, respecto de los cuales no se exige título profesional para ejercer su oficio. Por otra parte, se estimó que "el secreto bancario o mercantil tienen sustanciales diferencias, ya que en el primer caso el secreto protege los libros del comerciante en contra de la actividad de terceros que pretenden investigarlos; en cambio, en el segundo, se protege a los terceros que han depositado su confianza en ciertas personas que tienen título, como se desprende del ... artículo $247^{\circ}$, inciso 2 del Código Penal".

En materias de secreto bancario la tendencia de los tribunales chilenos ha sido la de limitar las facultades investigadoras de la hacienda pública (Servicio de Impuestos Internos) cuando está en juego la intimidad económica, propia del secreto bancario ${ }^{100}$.

señala que esta disposición es fuente del secreto bancario, es evidente que también lo es del derecho al secreto profesional, no obstante que este autor los concibe como derechos diferentes.

100 Ver Sentencia de la Corte Suprema en Banco O'Higgins con Director Nacional del Servicio de Impuestos Internos, de fecha 2 de abril de 1981 (Recurso de Protección). 
Entre las manifestaciones más relevantes del secreto profesional réstanos por señalar dos de ellas, que adquieren especial relevancia cuando nos enfrentamos a la protección de datos personales automatizados. Me refiero al secreto médico y al secreto estadístico.

En lo que respecto al primero, la legislación chilena (artículo $16^{\circ}$ del Decreto con Fuerza de Ley $N^{\circ} 196$ que fija el texto de la ley orgánica del Servicio Médico Legal), lo consagra en los siguientes términos: "El personal que preste sus servicios en el Servicio Médico Legal o en sus dependencias, estará obligado a guardar sigilo y será responsable, en conformidad a las leyes, si divulgare los hechos o los antecedentes de que tuviere conocimiento en razón de su empleo. En los casos en que los tribunales de justicia ordenen practicar reservadamente un examen médico-legal, sólo serán admitidas a presenciar la diligencia aquellas personas designadas por el juez y no podrán ser utilizados sus resultados en la enseñanza sin previa autorización del Tribunal respectivo".

Finalmente, en cuanto al secreto estadístico, el artículo $29^{\circ}$ de la Ley $\mathrm{N}^{\circ} 17.374$, de 10 de diciembre de 1970, que aprueba la Ley Orgánica del Instituto Nacional de Estadísticas, dice: "El Instituto Nacional de Estadísticas, los organismos fiscales, semifiscales y Empresas del Estado, y cada uno de sus respectivos funcionarios, no podrán divulgar los hechos que se refieren a personas o entidades determinadas de que hayan tomado conocimiento en el desempeño de sus actividades.

El estricto mantenimiento de estas reservas constituye el "secreto estadístico". Su infracción por cualquier persona sujeta a esta obligación hará incurrir en el delito previsto y penado por el artículo $247^{\circ}$, del Código Penal, debiendo en todo caso aplicarse pena corporal.

\section{Derecho a la intimidad y libertad de información.}

La libertad de expresión contó tradicionalmente en Chile, desde los inicios de la República, con un marco de regulación constitucional y legal que le servían de necesario sustento, perfilándose desde entonces su contenido y límites ${ }^{101}$. Con anterioridad incluso, al emblemático

101 El artículo $23^{\circ}$ del Reglamento Constitucional de 1812, establecía: "La imprenta gozará de una libertad legal; y para que ésta no degenere en licencia nociva a la religión, 


\section{Decreto del ministro Portales 102 , aún vigente. Las constituciones de $1833^{103}$, de $1925^{104}$ y de 1980 la han venido sucesivamente regulando.}

costumbres y honor de los ciudadanos y del país, se prescribirán reglas por el Gobierno y el Senado".

El artículo $11^{\circ}$ de la Constitución de 1818, señalaba: "Todo hombre tiene libertad para publicar sus ideas y examinar los objetos que están a su alcance, con tal que no ofenda a los derechos particulares de los individuos de la sociedad, a la tranquilidad pública y Constitución del Estado, conservación de la religión cristiana, pureza de su moral y sagrados dogmas; y, en consecuencia, se debe permitir la libertad de imprenta, conforme al reglamento que para ello formará el Senado o Congreso."

La Constitución de 1822 , en sus artículos $223^{\circ}$ y $225^{\circ}$, estableció: Sobre la libre manifestación de los pensamientos no se darán leyes por ahora; pero quedan prohibidas la calumnia, las injurias y las excitaciones a los crímenes". Y: "Es libre la circulación de impresos en cualquier idioma; pero no podrán introducirse obras obscenas, inmorales e incendiarias".

El artículo $7^{\circ}$ de la Ley de 14 de febrero de 1827, señalaba: "Se prohibe al Congreso, a las Asambleas y a todas las demás autoridades: $1^{\circ}$ Coartar en ningún caso ni por pretexto alguno la libertad del pensamiento, la de palabra, la de escritura y la de la prensa, procediéndose conforme a las leyes".

102 Este Decreto, dictado con fecha 14 de junio de 1830, decía lo siguiente: "15. Considerando que la imprenta bien dirigida es uno de los medios más poderosos para mantener la regularidad y pureza de los empleados en el desempeño de sus funciones públicas.

Considerando que el escandaloso abuso que se ha hecho de ella, convirtiéndole en un instrumento de pasiones maléficas, la incapacita para ejercer este saludable influjo, y lo hace más a propósito para extraviar, que para dirigir la opinión; que aún las acusaciones fundadas que se lanzan por la imprenta contra aquellos que abusan de sus facultades en daño público, no excitarán la atención que debieran vertiéndose por un órgano habitualmente depravado, que los acusados se escudan en la licenciosidad de la prensa para no sincerar su conducta; y que este orden de cosas, confundiendo a los buenos servidores del Estado con los prevaricadores, compromete igualmente el honor de todos ellos, y cede en desdoro del Gobierno.

He venido decretar y decreto:

$1^{\circ}$ Todo funcionario público, cuya conducta en lo que toca al ejercicio de su empleo, fuere atacado por la imprenta, debe acusar, por sí o por apoderado al autor o editor del impreso, ante el Tribunal competente y en el término de la ley.

$2^{\circ} \mathrm{Si}$ así no lo hiciere, queda suspenso, de hecho en el ejercicio de su empleo, y el Fiscal le acusará con el mismo impreso ante el Tribunal competente.

$3^{\circ}$ El Ministro del Interior queda encargado del cumplimiento de este Decreto.

Imprímase para que llegue a noticias de todos (Fdo.): Ovalle. Portales.

$103 \mathrm{El}$ artículo $12^{\circ} \mathrm{N}^{\circ} 7$ de la Carta de 1833 aseguraba a todos los habitantes de la República: "la libertad de publicar sus opiniones por la imprenta, sin censura previa, y el derecho de no poder ser condenado por el abuso de esta libertad, sino en virtud de un juicio en que se califique previamente el abuso por jurados, y se siga y sentencie la causa con arreglo a la ley".

104 El artículo $10^{\circ} \mathrm{N}^{\circ} 3$ de esta Carta aseguraba "la libertad de emitir, sin censura previa, sus opiniones de palabra o por escrito, por medio de la prensa o de cualquier otra forma, sin perjuicio de responder de los delitos o abusos que se cometan en el ejercicio de esta libertad en la forma y casos determinados por la ley". 
El ejercicio de la libertad de expresión y de la libertad de prensa constituye una de las tradiciones más respetadas de nuestra historia republicana, con la sola excepción de la etapa de interrupción constitucional sufrida por el país en 1973. Su regulación puede dividirse en seis períodos más o menos uniformes.

El primero, que corre desde la temprana época de ensayos constitucionales hasta la Constitución de 1833, se caracterizó por el amplio reconocimiento del derecho. Sin embargo, la prohibición explícita de la censura previa no vino a ser consagrada sino en esta última Constitución. Entre estos textos, el más limitativo para la libertad de expresión lo fue la Constitución "moralista" de 1823 (de muy corta aplicación) la que, no obstante declarar en su artículo $262^{\circ}$ la libertad de la imprenta, sometía, en su artículo $265^{\circ}$, a censura previa todo escrito que hubiera de imprimirse. Se entendía que dicha libertad estaba garantizada sólo "en cuanto contribuya formar la moral y las buenas costumbres; al examen y descubrimientos útiles de cuantos objetos pueden estar al alcance humano; a manifestar de un modo fundado las virtudes cívicas y defectos de los funcionarios en ejercicio; y a los placeres honestos y decorosos".

El segundo período, que corre a parejas con la República autocrática (1830-1861), se extiende desde el Decreto de Portales de 1830, hasta la dación de la Ley sobre Libertad de Imprenta, de 17 de julio de 1872. En este período, rigió la Ley de Imprenta de 16 de setiembre de 1846, que Ricardo Donoso definiría como una ley draconiana por su severidad $^{105}$ pese a que, en el hecho, no hubo de ser respetada y se convirtió prontamente en letra muerta. De otra parte, la Constitución de 1833 consagró, ya explícitamente, la prohibición de la censura previa.

El tercer período, coincidente con la República liberal (1861-1891) y con la República parlamentaria (1891-1925), se extiende desde la señalada Ley de Imprenta de 1872, hasta el Decreto Ley $N^{\circ} 425$ sobre Abusos de Publicidad y la Carta de 1925. Esta etapa, como las anteriores, tiene como singularidad, la aplicación del juicio por jurados ante los abusos cometidos por la prensa, mediante un sistema que puede ser valorado como excesivamente favorable a ésta. Al sustraerla del procedimiento común aplicable a los delitos de difamación ${ }^{106}$.

105 Ricardo Donoso. Las ideas políticas en Chile. p. 111 (citado por Andrade Geywitz en op. cit. p. 236).

$106 \mathrm{El}$ juicio por jurados para los abusos de la prensa fue introducido en Chile bajo la 
En el cuarto período, que se extiende durante toda la vigencia de la Constitución de 1925, se suprimió el juicio por jurados, y se dictaron, tanto una ley complementaria del Decreto Ley $\mathrm{N}^{\circ} 425$ sobre Abusos de Publicidad (la Ley No 15.476 de 23 de enero de 1964), como la Ley $\mathrm{N}^{\circ} 15.576$, de 11 de junio de 1964 , que sustituyó a la primera, fijando su texto refundido. El período se caracteriza por una regulación más pormenorizada del derecho, que incluye el establecimiento de responsabilidades penales para los medios de difusión. La legislación dictada en este tiempo va reflejando el impacto que las nuevas tecnologías producen en la práctica de esta libertad, como lo demuestra su extensión a la radio, a la televisión y a la cinematografía ${ }^{107}$. Por otra parte, a través de la reforma constitucional de 9 de enero de 1971, se introdujeron al $\mathrm{N}^{\circ} 3$ del artículo $10^{\circ}$ de la Constitución, varias disposiciones tendentes a garantizar con mayor fuerza su ejercicio. Así, por ejemplo el derecho de rectificación gratuito, el igual acceso de las distintas corrientes de opinión a los medios de comunicación y difusión privados, a la venta del papel, tinta o maquinaria utilizada por los medios, al derecho de las universidades a mantener estaciones de televisión, entre las más importantes.

El quinto período, sin duda el más nocivo para el ejercicio de la libertad de información ${ }^{108}$, es el que se prolonga entre el 11 de setiem-

inspiración del eminente hombre de letras y jurista español don José Joaquín de Mora, a través de la Ley de 11 de diciembre de 1828, principio que fue recogido por la Constitución de 1833. Sin embargo, la práctica del juicio por jurados no fue satisfactoria. El establecimiento del juicio por jurados llevó, según José Guillermo Guerra (La Constitución de 1925, p. 111, citado por Andrade Geywitz, en op. cit., p. 236) "a establecer el más completo libertinaje de prensa, y nuestro país se convirtió en el paráso de los calumniadores y difamadores, hasta el extremo que la calumnia, la injuria y la difamación producidas en forma horrorosamente dañinas por medio de la prensa, sólo merecía insignificantes penas, mientras las mismas iniquidades producidas de palabra o en pasquines manuscritos, que sin duda realizaban un daño mucho menor, podían ser sancionados con más rigor en conformidad a las disposiciones del Código Penal".

107 Otros textos legales aplicables durante este período, son los siguientes: 1) La Ley No 12.927, de 6 de Agosto de 1958 sobre Seguridad Interior del Estado, que en su título V, trataba "De los abusos de Publicidad", 2) El Decreto con Fuerza de Ley (DFL) N 37, No 37 , de $1^{\circ}$ de diciembre de 1959 , Ley Orgánica del Consejo de Censura Cinematográfica, su reglamento establecido por el Decreto $\mathrm{N}^{\circ} 3.823$, de 11 de agosto de 1960, del Ministerio de Educación y el DFL números 334 de 6 de abril de 1960, que modificó los dos textos anteriores, y 3) El Decreto $N^{\circ} 4.581$ del Ministerio del Interior, de 8 de octubre de 1949, que fijó el rexto definitivo del Reglamento de Transmisiones de Radiodifusión, entre otros.

108 En el Primer Informe sobre la Situación de los Derecho Humanos en Chile, de 1974, 
bre de 1973 y el 11 de marzo de 1990. En él se aplicó indiscriminadamente la censura previa, y el derecho de información sufrió los embates del arbitrio de la autoridad y la aplicación de las normas de excepción constitucional que rigieron al país durante aquella época. ${ }^{109}$

Finalmente, el sexto período, corresponde a la actual etapa de transición democrática, en el que el tema ha adquirido inusitada relevancia.

De manera muy semejante a la redacción utilizada por las instituciones de 1833 y 1925, y con ligeras pero sustantivas modificaciones en su expresión, el $\mathrm{N}^{\circ} 12 \mathrm{del}$ artículo $19^{\circ}$ de la actual Constitución Política del Estado, establece como garantía:

" $12^{\circ}$ La libertad de emitir opinión y la de informar, sin censura previa, en cualquier forma y por cualquier medio, sin perjuicio de responder de los delitos y abusos que se cometan en el ejercicio de estas libertades, en conformidad a la ley, la que deberá ser de quorum calificado".

Las principales novedades que se introducen, en relación a la Constitución de 1925, es la diferenciación entre la libertad de emitir opinión y la libertad de informar, no contenida en la anterior Constitu-

la Comisión Interamericana de Derechos Humanos dirigió al Gobierno la siguiente recomendación: " $8^{\circ}$ Que para tutelar los derechos a que se refiere el artículo IV de la Declaración Americana, se adopten medidas que progresivamente tiendan a la restauración de la libertad de expresión del pensamiento, tanto en su ejercicio puramente individual como a través de los medios de comunicación masiva, sin perjuicio de que se hagan efectivas las responsabilidades en que puedan incurrir quienes abusen en el ejercicio de tal libertad, con arreglo a lo que disponga la legislación ordinaria sobre la materia”. Citado por Thomas Buergenthal, Robert E. Norris y Dinah Shelton, en "La Protección de los Derechos Humanos.l..", op.cit., p. 419. Estas recomendaciones y llamadas al gobierno chileno para asegurar la plena vigencia de los derechos humanos fueron práctica sucesiva de la Comisión.

109 Las normas vigentes en esta época estaban más orientadas a la sanción de ideas que de conductas. Como manifestara Andrade Geywitz (en Reforma de la Constitución Política de la República de Chile de 1980, Editorial Jurídica de Chile, Santiago 1991, p. 204), ellas importaban un verdadero apartheid cívico. Ejemplo de lo anterior son las leyes $\mathrm{N}^{\circ} 16.643$ sobre Abusos de Publicidad, que en su artículo $4^{\circ}$, prescribía elevadas sanciones a quienes "hagan apología de las organizaciones, movimientos o partidos políticos declarados inconstitucionales o continuadores de éstos o hagan propaganda de sus actividades...", y el artículo $2^{\circ}$ de la Ley No 18.662, que disponía en idéntico sentido. Inserciones de la Asociación Nacional de la Prensa (noviembre de 1987) consideraron que estas normas afectaban la libertad de expresión "en su esencia". 
ción, y en la necesidad de una ley de quórum calificado para su regulación ${ }^{110}$. Pero, además de estas diferencias, se introducen nuevas normas, en las que se hace referencia a la prohibición del monopolio estatal sobre los medios de comunicación social, al derecho a fundar, editar y mantener diarios, revistas y periódicos, al régimen de televisión y a la censura en la exhibición y publicidad de la producción cinematográfica.

En lo que respecta al derecho de recibir la información, el Acta Constitucional $\mathrm{n}^{\circ} 3$ de 1976, antecedente de la Constitución de 1980, la establecía, pero la Comisión de Estudios de la nueva Constitución, estimó que no era necesario agregarla, porque se encontraba implícitamente envuelta en la libertad de opinión y comunicación. Asimismo, la Comisión entendió "que en la garantía constitucional de que se trata, hay dos bienes jurídicos en juego: uno de carácter personal o individual, que es el derecho de emitir opinión y de informar, y otro de carácter social, que es el derecho de recibir la información, opiniones y expresiones que los demás quieran transmitir, derecho este último que corresponde a la comunidad toda"111.

Por libertad de opinión debe entenderse, como señala José Luis Cea, "la facultad que tiene toda persona de exteriorizar, por cualquier medio y sin coacción, lo que piensa o cree" ${ }^{\text {"12. }}$. Esta fue, por lo demás, la definición adoptada por la Comisión Constituyente ${ }^{113}$. La médula de la garantía consiste en que se ejerce sin censura previa ${ }^{114}$. La libertad de informar, por otra parte, es considerada como un supuesto indispensable de la libertad de opinión y comprende: 1) la libertad de acceso a las fuentes de información y opinión, 2) la libertad de difundir o comu-

110 En el sistema de fuentes chileno, la Constitución distingue, en su artículo $63^{\circ}$, entre leyes interpretativas, orgánicas, de quórum calificado simples. Las primeras requieren para su aprobación, modificación o derogación de las tres quintas partes de los diputados y senadores en ejercicio; las segundas, de las cuatro séptimas partes y las terceras, la mayoría absoluta. "Las demás normas legales -dice la Constitución- requerirán la mayoría de los miembros presentes de cada Cámara, o las mayorías que sean aplicables conforme a los artículos $65^{\circ}$ y siguientes".

111 Enrique Evans de la Cuadra. Op. cit., p. 300.

112 José Luis Cea Egaña. Tratado de la Constitución de 1980. Características Generales. Garantías Constitucionales. Editorial Jurídica de Chile, Santiago de Chile, 1988, p. 97.

113 Así consta del oficio enviado con fecha 16 de agosto de 1978 al Presidente de la República. Citado por Enrique Evans, en p. 299 de op. cit.

114 Enrique Evans de la Cuadra. Op. cit., p. 302. 
nicar lo hallado en tales fuentes o que proviene de ella y 3) la libertad de recibir la información ${ }^{115}$.

Pese a la amplitud que se quiso dar al precepto del $n^{\circ} 12$ del artículo $19^{\circ}$ de la Constitución, la Comisión se inspiró en una concepción del pluralismo más restringida que la adoptada por la anterior Carta constitucional. Así quedó de manifiesto en el curso del debate realizado durante la Sesión $N^{\circ} 235$ de la Comisión, en la que uno de sus miembros, Jaime Guzmán Errázuriz, sostuvo que: “... hay que apartarse aquí del concepto de pluralismo ideológico irrestricto consagrado en el Estatuto de Garantías Constitucionales de 1971, que decía que no podrá ser constitutivo de delito sustentar o difundir cualquier idea política. Es evidente que la Comisión Constituyente está trabajando sobre el marco de un pluralismo ideológico limitado, restringido, que tenga como marco admisible todo aquello que sea congruente con las bases fundamentales de la institucionalidad, pero no aquello que vaya más allá de ella, alterando lo que es el sistema constitucional en su esencia”, concepto que ya había sido sostenido en sesiones anteriores (v. gr. Sesión $n^{\circ} 230$ ). Sin rebatir directamente esta idea, en el curso de la misma sesión Alejandro Silva Bascuñán defendió la tesis de que no se podía distinguir entre ideas políticas y otras categorías de ideas, y que ambas debían quedar sometidas a un régimen de regulación general. Esta opinión manifestada por Guzmán, y aceptada por otros miembros de la Comisión, es el resultado lógico del integrismo político e ideológico que inspiraba a algunos de sus integrantes, el que se expresa de un modo muy claro, a nuestro juicio, en la siguiente opinión vertida por el Presidente de dicha Comisión, el Sr. Enrique Ortúzar Escobar. Desde luego el Sr. Ortúzar reconoce que "la libertad de expresión es absolutamente consustancial a una democracia", pero acto seguido propone que se establezca como uno de los requisitos para ejercer la titularidad de un medio de comunicación el "no profesar ideologías contrarias a las bases esenciales de la institucionalidad". Para el Presidente de la Comisión debía agregarse, como principio, al Capítulo I, "el rechazo de la lucha de clases", porque al corresponder al Estado la promoción del bien común: “... también debe propender ... (a) ... la integración

115 Todo ello se desprende de los debates realizados en el seno de la Comisión de Estudios de la Nueva Constitución en sus sesiones 227 a 242, 280, 310 y 357, todas las cuales se dedicaron al análisis de esta libertad. 
armónica de todos los sectores de la comunidad, y, por tanto, al rechazo de esa lucha”. Esta última alusión, sin embargo, no llegó a formar parte del inciso quinto del artículo $1^{\circ}$ de la Constitución.

Esta misma perspectiva totalizadora, integrista, o, como hoy diría un filósofo del derecho, perfeccionista, fue sustentada por Guzmán Errázuriz, para quien el "marco admisible de discrepancia" no incluye las disposiciones iniciales de la Constitución sobre Bases de la Institucionalidad" (Sesión 229, de 6 de julio de 1976).

Pero, a pesar de la importancia excesiva que los operadores de la Constitución suelen dar a las opiniones vertidas por los miembros de la Comisión, sostenemos que desde la reforma constitucional de 17 de agosto de 1989, que derogó el controvertido artículo $8^{\circ}$ de la Carta, ya no puede seguir sosteniéndose una tesis semejante ${ }^{116}$. Si como ha dicho el profesor Lucas Verdú "los preceptos constitucionales conectan con la conciencia y el sentimiento constitucionales de la sociedad civil" 117 , es evidente que esa reforma fue impulsada por un sentimiento constitucional que buscaba para el país el restablecimiento de una democracia plena y plural, no sujeta a tutelas ideológicas ni políticas ${ }^{118}$. La misma norma del artículo $1^{\circ}$ inciso 4 de la Constitución establece

116 Esta tesis fue, sin embargo ampliamente admitida por el Tribunal Constitucional, con anterioridad a la reforma de la Constitución del año 1989, en la Sentencia de 21 de diciembre de 1987, en el que acogió el requerimiento del Ministro del Interior de la época en contra del ex Canciller del Presidente Allende, Clodomiro Almeyda, por "haber incurrido en actos que propagan doctrinas que propugnan la violencia como también en actos que propagan doctrinas que propugnan una concepción de la sociedad, del Estado o del orden jurídico de carácter totalitario, e igualmente en actos destinados a propagar doctrinas fundadas en la lucha de clases".

117 Pablo Lucas Verdú. El Sentimiento Constitucional. Aproximación al estudio del sentir constitucional como modo de integración política. Instituto Editorial Reus S.A., Madrid, 1985 , p. 119.

118 Cfr. Francisco Geisse y José Antonio Ramírez Arrayas. La Reforma Constitucional. Ediciones Chile-América CESOC, Santiago, 1989, pp. 18 y 19. Han sostenido estos autores, p. 26: "Pluralismo implica la facultad de elegir libremente entre diversas alternativas. Ello supone el uso sin restricciones de todos los medios lícitos adecuados a la determinación de los destinos personales y colectivos. Para su logro, reviste vital importancia el igualitario acceso a los medios de comunicación, constituyendo un deber del Estado garantizar el derecho a la información y la opinión. Por otra parte, la tolerancia nos lleva al respeto por las ideas y posiciones diversas. Significa no pensar que la verdad absoluta es propiedad de una determinada colectividad política. Implica, pues, en último término, la eliminación de cualquiera discriminación ideológica, y en tal sentido, la tolerancia es incompatible con el artículo $8^{\circ}$ que se consagró en el texto original de la Carta Política de 1980, hoy sustituido en el proyecto de reforma por el artículo $19^{\circ} \mathrm{N}^{\circ} 15^{\prime \prime}$. 
el principio según el cual: "El Estado está al servicio de la persona humana y su finalidad es promover el bien común, para lo cual debe contribuir a crear las condiciones sociales que permitan a todos y cada uno de los integrantes de la comunidad nacional su mayor realización espiritual y material posible, con pleno respeto a los derechos y garantías que esta Constitución establece" (el subrayado es nuestro). En esta misma línea la Ley de Reforma Constitucional $\mathrm{N}^{\circ} 18.825$, agregó un nuevo inciso al $\mathrm{N}^{\circ} 15$ de la Constitución en el cual, zanjando esta discusión, se proclama expresamente que: "La Constitución Política garantiza el pluralismo político”.

En lo demás, la casi totalidad de los miembros de la Comisión coincidieron en que la libertad de expresión es "la más sensible de las libertades públicas" (Evans, Sesión N²29, de 6 de julio de 1976), "la base y el resorte sustancial de la democracia política" (Silva Bascuñán, en la misma Sesión señalada), "uno de los derechos constitucionales más importantes y fundamentales dentro de las garantías constitucionales (Lorca, en Sesión 230, 7 de julio de 1976)", absolutamente consustancial a una democracia (Ortúzar, en la misma Sesión anterior), uno de los problemas "... más importantes ... de toda institucionalidad moderna”. (Guzmán, Sesión No 227 de 30 de junio de 1976).

Pero pasemos a ver ahora la referencia a sus límites.

De modo semejante a la Constitución de 1833 y de 1925, la Constitución de 1980 no estableció expresamente los límites intrínsecos y extrínsecos a las libertades de opinión y de información y dejó entregada esta importante tarea al legislador. Sólo que esta vez por medio de un mecanismo de mayoría reforzada de senadores y diputados. Los "delitos" y "abusos" que se cometan en el ejercicio de estas libertades deberán ser regulados por ley de quórum calificado (mayoría absoluta de senadores y diputados en ejercicio).

Sin embargo, la libertad del legislador en esta materia no es absoluta. A ello se opone la norma del artículo $19^{\circ} \mathrm{N}^{\circ} 26$ de la Constitución. De acuerdo a este artículo, que tiene indudables semejanzas con el artículo $19^{\circ}$ de la Ley Fundamental de Bonn, que le sirvió de fundamento, y con el artículo $53^{\circ}$ de la constitución española: "La Constitución asegura a todas las personas ... $26^{\circ} \mathrm{La}$ seguridad de que los preceptos legales que por mandato de la Constitución regulen o complementen las garantías que ésta establece o que las limiten en los casos en que ella lo autoriza, no podrán afectar los derechos en su esencia, ni 
imponer condiciones, tributos o requisitos que impidan su libre ejercicio".

Ahora bien, en una reciente sentencia recaída sobre el Proyecto de Ley sobre libertad de opinión e información, el Tribunal Constitucional chileno se ha pronunciado sobre el contenido esencial de esta libertad. Ha dicho el Tribunal que "la esencia del derecho que nos preocupa está en que éste se ejerza libremente y que no exista censura previa que lo afecte" (Considerando 10 de la Sentencia) ${ }^{119}$.

Los proyectos de legislación en materia de libertad informática

Corresponde, ahora, vincular la temática anterior con proyectos de legislación de la libertad informática.

Podemos diferenciar, a lo menos, cuatro etapas en los intentos locales de regulación del tema que nos ocupa. La primera de ellas, corresponde a los proyectos elaborados durante el régimen militar por la comisión designada por el ministro de Justicia de la época. La segunda, es coincidente con el proyecto elaborado durante el gobierno del Presidente Aylwin por la Comisión nombrada por el ministro Cumplido. La tercera corresponde a algunas mociones legales presentadas en fechas recientes, que han sufrido diversa suerte $y$, especialmente a la moción del senador Cantuarias y a las disposiciones incorporadas en el Proyecto de Ley sobre las libertades de opinión e información y el ejercicio del periodismo. La última la hacemos coincidir con el giro que toma la moción Cantuarias, mediante la discusión en la Comisión de Constitución, Legislación y Justicia de la Cámara de Diputados, durante el análisis de la misma, tal y como fuera remitida a esta Cámara por el Senado de la República.

\section{a. Los proyectos de la Comisión Hajna}

Entre los meses de abril y noviembre de 1985 se realizaron en Chile los primeros esfuerzos dirigidos a legislar en materia informática. Para estos efectos se creó, durante ese año, en el Ministerio de Justicia, una Comisión presidida por el Sr. Eduardo Hajna, que elaboró un anteproyecto de ley informático que fuera remitido en consulta a distintas organizaciones relacionadas con la materia. Sobre la base de las respues-

119 Sentencia del Tribunal Constitucional, Rol $N^{\circ} 226$ de 30 de octubre de 1995. 
tas recibidas se elaboró, en septiembre de 1986, el primer proyecto de ley informático realizado en Chile. Sin embargo, el proyecto fue sometido a sucesivas revisiones, que dieron lugar a nuevas versiones del mismo en abril de 1986, febrero de 1987, mayo de 1987 y junio de 1988.

Estos proyectos que contenían ya gran parte de los aspectos más definitorios de las leyes de protección de datos, no derivaron nunca, pese a ello, en textos legales positivos. Entre las dificultades que tuvo la materialización de estos proyectos, se encuentra, probablemente, el intento por parte de las comisiones constituidas durante el régimen militar de resolver, en un solo cuerpo legal, todos los aspectos relativos a la informática; esto es, la regulación de aspectos tan variados como el delito informático, la regulación de software y el hardware, la modificación del sistema chileno de pruebas y la protección de la libertad informática.

Tratándose de proyectos iniciales en la materia, podemos constatar en ellos algunas deficiencias en la regulación de los derechos de las personas afectadas en el tratamiento automatizado de los datos personales, entre las que podemos mencionar, la ausencia de regulación del llamado derecho de impugnación. Este derecho se ejerce frente a los actos administrativos o decisiones privadas que implican una valoración del comportamiento de una persona, cuando tiene como único fundamento el tratamiento automatizado de sus datos de carácter personal. En lo que toca al derecho de acceso, se confunde éste, en su tratamiento, con el derecho de información.

Finalmente, si bien es cierto que estos proyectos consignaron el llamado derecho a corregir las informaciones inexactas contenidas en un archivo de datos, como la obligación del responsable del archivo de comunicar la corrección efectuada a las entidades a que se haya cedido la información o a aquellas de quienes las recibió, no señalan un plazo para que el responsable del fichero cumpla con su deber de rectificar.

Respecto del derecho de cancelación, se entiende que éste debe operar respecto a informaciones que lesionan la vida privada del afectado, lo que a nuestro juicio revela una incomprensión respecto del bien jurídico protegido, el que no se reduce, pura y simplemente al derecho a la vida privada.

La principal crítica que puede formularse a este proyecto se debe a la ausencia de disposiciones destinadas a establecer una autoridad de control de las bases de datos constituidas por el sector público o los 
particulares, situación que habría ocasionado un menoscabo en el ejercicio de los derechos por parte de las personas afectadas.

\section{b. El proyecto elaborado en 1993, durante el Ministerio Cumplido}

El proyecto elaborado por esta Comisión importa un notable avance en relación con los proyectos anteriores. Sin embargo, y pese a que en relación a ellos, incorpora a su tratamiento, derechos como el de impugnación, mantiene una regulación conjunta de los derechos de acceso y de información, a los que debió tratar en forma separada.

Desde un punto de vista formal, el proyecto puede ser objeto de crítica en cuanto a la forma de regular los derechos de los afectados, que pudo haber sido más específica y pormenorizada, aunque debe destacarse que incorpora la existencia de un organismo de control de naturaleza independiente al que denomina Servicio Nacional de Protección de Datos.

No sería extraño que la misma consideración de este organismo de control haya sido la causa de que el proyecto quedara bloqueado en su tramitación al interior del propio Gobierno. ¿Las razones? Posiblemente la falta de simpatía frente a la idea de la creación de un nuevo organismo que había de implicar un crecimiento de la burocracia estatal.

El proyecto, que sigue muy de cerca la ley española de protección de datos de 1992, tenía, sin embargo, el inconveniente de dejar fuera de sus disposiciones a las bases de datos de las Fuerzas Armadas y de los servicios policiales y de inteligencia, tema delicadísimo, que optó por remitirlo a la regulación de sus propios estatutos internos.

Evidentemente una solución de esta clase había de estar fuera del marco establecido por la propia Constitución para la regulación de los derechos constitucionales, los que jamás pueden quedar entregados a la pura órbita del reglamento.

c. La moción original del senador Cantuarias y las disposiciones incorporadas en el proyecto de ley sobre las libertades de opinión e información y el ejercicio del periodismo.

c.1. La moción del senador Cantuarias

c.1.1. Su tramitación ante el Senado 
Con fecha 5 de enero de 1993, se dio cuenta en la Sala del Senado de una moción presentada por el senador Cantuarias, con la que inicia un proyecto de ley sobre protección de la vida privada. El proyecto queda incluido en la convocatoria a la legislatura extraordinaria de sesiones del Congreso Nacional.

La pretensión de su autor es la de brindar "una adecuada protección a la privacidad de las personas en el ámbito del Derecho Civil, donde se evidencia un vacío en nuestra legislación. Se trataría, de crear un Código o Estatuto Jurídico de la Privacidad.

El texto se inspira -como se señala en la misma moción-, fundamentalmente, en la Ley Orgánica $N^{\circ} 1$, española, de protección civil del derecho al honor, a la intimidad personal y familiar y a la propia imagen; en la ley francesa de informática, ficheros y libertades de 1978; y en las leyes de protección de datos de Noruega (1978) y Gran Bretaña (de 1984), entre otros textos, de los que cita el Código Civil argentino y el Código Civil francés.

El proyecto se divide en cuatro capítulos, de la siguiente manera: el Título I, establece disposiciones generales, el Título II se refiere a la protección de los datos, el Título III, a las intromisiones ilegítimas en la vida privada; $y$, el Título IV, al Tribunal competente y al procedimiento.

El Proyecto tiene, indudablemente, la virtud de ser el primero que logra iniciar sin tropiezos su iter legislativo y de poner por primera vez en discusión en el Parlamento, la necesidad de atender a una regulación de la vida privada, fijando el contenido del derecho proclamado en el artículo $19^{\circ} \mathrm{N}^{\circ} 4$ de la Constitución de una manera sistemática.

$\mathrm{Su}$ autor, sin embargo, parece no tener presente, en esta primera etapa, las disposiciones de la entonces reciente Ley Orgánica de Tratamiento Automatizado de Datos Personales de España, que fuera dicta$\mathrm{da}$, precisamente, durante el año anterior, como directo corolario de las presiones recibidas por el Gobierno español de parte del Consejo de Europa en orden a regular estas materias. Tampoco toma en consideración los diversos proyectos sometidos a tramitación legislativa en el Parlamento italiano.

La moción contiene 26 artículos, de los cuales, la mayor parte de ellos está dirigida a regular la protección de los datos personales.

Son pocas las disposiciones encaminadas al establecimiento del Estatuto de la vida privada, no obstante que avanza en algunos sentidos 
al concebir la vida privada como comprensiva de, a lo menos, cuatro bienes jurídicos a los que se estima dignos de protección. Esto es (artículo $2^{\circ}$ ): a) el derecho a la propia imagen, b) el derecho a la intimidad personal y familiar, c) el anonimato y reserva, d) el derecho a una vida tranquila, sin hostigamientos ni perturbaciones; $y, d$ ) el derecho a la inviolabilidad del hogar y de toda forma de comunicaciones privadas.

Por cierto, varios de estos derechos no se encuentran contemplados en la regulación constitucional de la vida privada de los artículos $19^{\circ}$ $\mathrm{N}^{\circ} 4$ y $19^{\circ} \mathrm{N}^{\circ} 5$, pese a que en el caso del derecho a la propia imagen la Comisión de Estudios de la Nueva Constitución, consideró, como nos recuerda Evans de la Cuadra, que se entendía incorporado en el derecho a la vida privada del artículo $19^{\circ} \mathrm{N}^{\circ} 4$.

El artículo $14^{\circ}$ de la moción establecía un catálogo, aunque abierto, de los casos que deberían ser considerados como intromisiones ilegítimas en la vida privada de una persona, haciendo referencia, especialmente, a la utilización de medios técnicos destinados a reproducir la imagen o la voz de una persona con el objeto de reproducir o conocer la vida íntima de las mismas. Las letras a) y b) de esta disposición, que se refieren a la materia, no distinguen a si el lugar en que se utilizan esos medios técnicos son públicos o privados y sólo mira a la finalidad de su utilización.

En el transcurso del debate de la iniciativa en el Senado, y a la luz de algunos informes agregados a los antecedentes, se fueron decantando ciertos aspectos. Así, por ejemplo, en su primer informe, la Comisión de Constitución, Legislación y Justicia, optó por suprimir del artículo segundo de la moción, la referencia que hacía al derecho del anonimato y de reserva ${ }^{120}$, por cuanto a juicio de la Comisión: "Hay determinados antecedentes que no deben permanecer desconocidos, sin romper el justo equilibrio entre el derecho a la privacidad que le asiste a toda persona y el hecho de que ella vive en sociedad". Se trataba de evitar la colisión con el legítimo ejercicio de la libertad de información.

Del mismo modo, entre las modificaciones relevantes de la Comisión de Constitución del Senado, se optó por reducir el universo de la

120 Durante el debare, el senador Cantuarias estimó que este derecho apunta "en la dirección de que los datos de las personas que figuran en los registros de determinadas instituciones, organismos y servicios, no puedan ser dados a conocer por éstos, sin aurorización expresa del titular". 
casuística del artículo $14^{\circ}$ respecto de las intromisiones ilegítimas en la vida privada, para dejar solamente la descripción más general que se hace en la última letra del precepto. Es decir, que hay intromisión ilegítima en la vida privada de una persona en todo acto u omisión arbitrario o ilegal que moleste, perturbe, amenace o prive a una persona del ejercicio legítimo del derecho a su vida privada.

Por indicación de la senadora Feliú se dejó constancia de la supresión de la referencia, en el artículo segundo, a la expresión: "una vida tranquila, sin hostigamiento ni perturbaciones" por considerarse que ella es una consecuencia, una "aplicación de la intimidad".

Desde luego, no corresponde efectuar aquí una transcripción completa del desarrollo de la discusión de esta moción en el Senado. Solamente hemos resaltado algunos de los temas que nos han parecido más relevantes en la misma. Ciertamente, otros aspectos, como los relativos a la indemnización de perjuicios o a aspectos específicos del tratamiento de los derechos de los afectados resultan de gran interés.

Pese a todo, debemos señalar cuáles son las grandes líneas de apreciación crítica que podemos destacar en el proyecto remitido por el Senado a la honorable Cámara de Diputados.

Ellas son, a nuestro juicio, las siguientes:

1. Una cierta falta de comprensión respecto a que el bien jurídico protegido a través de las técnicas de protección de datos no se reduce exclusivamente al derecho a la vida privada. Queda claro de la sentencia del Tribunal Constitucional Alemán recaída sobre la Ley del Censo de 1983, que basta con la presencia de datos absolutamente aislados, que no digan relación alguna con la intimidad, para que la lesión al derecho de autodeterminación informativa pueda producirse a consecuencia de la vinculación de estos datos y de la construcción de un perfil del individuo que no corresponde a su personalidad.

Ha sido ampliamente demostrado que la tendencia seguida por algunas legislaciones, como la norteamericana y la italiana, consistente en subsumir bajo la figura de la privacy o de la riservatezza, el conjunto cada vez más amplio de atentados posibles en contra del derecho a la intimidad, conduce inevitablemente a un desperfilamiento cuantitativo y cualitativo de las figuras jurídicas que sirven de marco a este procedimiento.

Puede observarse en el iter legislativo de los proyectos chilenos so- 
bre la materia, que el segur la tendencia indicada ha ido generando sucesivas confusiones y traslapes normativos en el desarrollo y discusión de estos proyectos que, afortunadamente, han podido ir salvándose, sucesivamente, en este proceso.

Pero las evidencias son claras: se regula un conjunto de derechos que se entiende pertenecen a la esfera del derecho a la vida privada: derecho al anonimato y reserva o el derecho a una vida tranquila sin hostigamientos ni perturbaciones, derecho a la propia imagen. La lista podría haber sido extendida ad infinitum, ya que la enumeración contenida en la moción era simplemente ilustrativa.

El profesor Gastón Gómez ya advertía en su informe al Senado sobre las consecuencias que el método podía ocasionar respecto de la procedencia del recurso de protección. Ponía en tela de juicio el que el recurso fuera procedente respecto de figuras no contempladas, de manera expresa, en el artículo $19^{\circ} \mathrm{N}^{\circ} 4$ de la Constitución, como es el caso, por lo demás, del derecho a la propia imagen.

2. Junto a lo anterior, la moción incurre en una pretensión parecida a la que, posiblemente, hizo fracasar los proyectos de la Comisión Hajna: el querer regular todo el marco de situaciones referentes a la vida privada. En efecto, como hemos dicho, la moción está compuesta por normas destinadas a regular la vida privada de las personas y, en cierto modo, a establecer una línea divisoria entre el concepto de lo público y lo privado (artículo $14^{\circ}$ ), fijando las pautas de lo que consideraba las intromisiones ilegítimas en la vida privada de los individuos.

Sin embargo, la mayor parte de sus disposiciones están orientadas a regular el tratamiento automatizado de datos personales, aunque sus disposiciones en esta materia no han sido, en ningún caso, exhaustivas.

3. En relación a los derechos del afectado, detectamos los siguientes problemas:

a. La confusión entre el derecho de acceso y el derecho de información, en el artículo $11^{\circ}$. La moción parece no comprender esta importante diferencia $y$, en la medida que no se contempla en ella una autoridad pública que controle y ponga a disposición de los ciudadanos las listas de archivos de datos que registra, la garantía servirá de poco en la medida que será muy difícil que el afectado pueda tomar conocimiento de la existencia de datos que le conciernen. 
b. Una regulación muy incompleta, en el artículo $12^{\circ}$, de los derechos de rectificación y cancelación.

En síntesis, podemos afirmar que si bien el proyecto tiene la virtud de iniciar la discusión sobre el tema de la protección de datos, es todavía, en su etapa inicial, muy imperfecto y sujeto a toda clase de correcciones.

\section{c.1.2. Su tramitación ante la Cámara de Diputados}

La moción del senador Cantuarias, bastante modificada por el Senado antes de su envío a la Cámara, sufre en la Cámara de Diputados una transformación sustancial, que cuenta, por lo demás, con el asentimiento de su autor.

La Comisión de Constitución, Legislación y Justicia de la Cámara de Diputados estimó oportuno encomendar a dos de sus diputados, los sres. José Antonio Viera Gallo y Luis Valentín Ferrada, la redacción de un nuevo texto abocado directamente a regular la protección de las personas frente al tratamiento automatizado de sus datos personales.

La decisión de la Comisión ha sido, sin duda, muy acertada, y mejora de manera sustancial la moción original, encaminándose en la perspectiva clásica de las técnicas de protección de datos.

El nuevo proyecto se articula sobre la base de cuatro títulos y un título preliminar. Este último establece disposiciones generales, fijando el principio inspirador de la ley, la definición de datos personales y el derecho a información de los afectados. El Título I, regula el procesamiento y utilización de datos personales; el Título II, los derechos de las personas afectadas; el Título III, el procesamiento y utilización de datos personales por los medios de comunicación social y, finalmente; el Título IV, las sanciones y acciones a que da lugar la ley.

Si bien es cierto que, como hemos dicho, el nuevo proyecto emanado de la Comisión de Constitución de la Cámara, se encamina en el correcto sentido, en la medida que opta por proteger los datos y no por continuar en la espinosa senda de pretender un estatuto global de la privacidad en el que se incluye la protección de los datos junto a un variopinto universo de bienes jurídicos, es necesario introducir algunas modificaciones de fondo y forma.

Por esta razón manifestamos ahora nuestras principales apreciaciones en torno al "nuevo" proyecto. Ellas son las siguientes: 
A. En cuanto a los aspectos de fondo, esto es, a los que tienen relación con las ideas inspiradoras del proyecto, nos parece denotar en él tres perspectivas inspiradoras, referidas tanto a los aspectos de principio, como al ámbito de aplicación de futura ley y al sistema de control preferido.

A.1. En relación al principio inspirador, el proyecto parte de la base de reconocer a toda persona el derecho a recolectar, procesar, custodiar y transferir datos. Así lo expresa en su artículo primero, agregando luego, en el segundo inciso, que reconoce este derecho con el "propósito de proteger a las personas por el uso que terceros puedan hacer de sus datos personales".

Se trataría, entonces que el legislador fije los límites a este derecho a la libre recolección, proceso, custodia y transferencia de los datos.

Nos parece que un tal tratamiento del problema nos lleva a situar su conceptualización jurídica, precisamente, en el terreno menos oportuno, porque lo que las técnicas de protección de datos tratan de lograr no es ampliar las posibilidades jurídicas de individuos para recoger informaciones sobre los demás, sino precisamente todo lo contrario.

El punto de partida para la teoría de la protección de datos es que los medios técnicos facilitan de un modo altamente inconveniente la circulación de informaciones sobre datos personales de los individuos que, incorporados en registros manuales o automatizados, pueden derivar en la elaboración de un perfil postizo de la personalidad de un sujeto.

No se piense, sin embargo, que lo que queremos afirmar es el aspecto de la intimidad que se vincula a su clásico reconocimiento como libertad negativa, al derecho a ser dejado solo formulado por el juez Cooley ${ }^{121}$.

Muy lejos estamos de una perspectiva semejante, tanto porque creemos que el concepto moderno de intimidad supera ampliamente su conceptualización como libertad negativa y que hoy más bien debe pensarse como un derecho que permite a los individuos positivamente controlar aquellos aspectos que, a su juicio, deben permanecer bajo alguna esfera de reserva, como porque tratándose de la protección de

121 Thomas Cooley. A treatise on the Law of torts or the wrongs which arise independenttly of contract. Callaghan, Chicago, 1932. 
datos estamos en presencia de un derecho autónomo distinto a la intimidad, con un perfil propio.

De manera que, si se quiere comprender bien el fenómeno que debe ser objeto de la regulación, se debe partir de la base de reconocer el derecho a la libertad informática de los individuos y no el derecho general a recolectar y difundir información porque, este último, si hemos de concebirlo como un derecho, está llamado a ocupar un lugar distinto del que es ahora objeto de preocupación por los legisladores.

Por lo demás, así lo entendió don José Antonio Viera Gallo en la sesión de la Cámara de Diputados de martes 30 de julio de 1996, cuando informó el proyecto, al señalar que "el hecho de recoger y registrar datos personales constituye una limitación en la esfera de los derechos de las personas", es decir, lo contrario de lo que expresa el artículo primero. A mayor abundamiento, y después de citar que el proyecto se basa, principalmente, en las leyes alemana y española y de referir cómo el Tribunal Constitucional alemán ha reconocido el derecho a la autodeterminación informativa, el diputado Viera Gallo ha dicho: "Eso es lo que hace este proyecto: determina una limitación a la libertad de información y, al mismo tiempo, establece una habilitación de quién y cuándo puede recoger los datos personales".

b. Desde el punto de vista del ámbito de aplicación, nos parece que si bien el proyecto no distingue entre bases de datos públicas o privadas, la forma de su registro y la limitación a que los registros privados sujetos a esta obligación son únicamente los "organizados con la finalidad de darlos a conocer a terceros" (artículo 13, inciso segundo del proyecto), denota el mayor temor del legislador frente a la información controlada por la administración. De otra manera no se explica que se haya optado por entregar la actividad de registro a la Contraloría General de la República.

Es evidente que la concentración de informaciones en el seno del Poder Ejecutivo y de la administración, es un riesgo que hay que precaver en garantía de la libertad, pero no debe perderse de vista que en la sociedad moderna los grandes centros de información y la mayor concentración del poder informático no se encuentra, precisamente, en los órganos del Estado.

Y aquí lindamos con otros aspectos interesantes de la protección, en la medida que en relación al derecho de autodeterminación se hace plenamente justificable la teoría de la drittwirkung, es decir, aquella 
teoría de acuerdo con la cual los derechos constitucionales no sólo tienen eficacia frente a la administración en su forma tradicional de derechos públicos subjetivos que se ejercen frente al Estado, sino que también vinculan a los particulares.

c. En cuanto al sistema de control. El "proyecto de la Cámara" opta por establecer un sistema de Registro, al estilo anglosajón, pero con la particularidad de que éste deberá ser efectuado ante la Contraloría General de la República.

¿Cuáles son las dificultades que vemos en esto? Principalmente tres:

a. Que la obligación de registro solamente está concebida para los registros públicos y que, del tenor del artículo $13^{\circ}$ inciso segundo del proyecto, pareciera que no pesaría esta misma obligación para las bases de datos del sector privado.

b. Que la Contraloría se limita a efectuar materialmente el registro y a actualizarlo, sin que se le dote de facultades explícitas de vigilancia, más que aquellas que en su carácter de órgano contralor de la administración le corresponderían de acuerdo a las normas generales. Pero, ¿quién controlará las bases de datos privados?

Un principio básico de las técnicas de protección de la libertad es el que nos ha recordado el profesor Vanossi en una publicación, sobre el Hábeas Data, en una revista jurídica argentina (El Derecho). El dice, mas o menos, lo siguiente: "a una mayor posibilidad de lesión de la libertad corresponde paralelamente incrementar los mecanismos de control".

No parece estar, sin embargo, presente aún esta idea en el proyecto que analizamos, aun cuando esperamos que en el proceso de perfeccionamiento a que invita el diputado Viera Gallo ${ }^{122}$, en la misma sesión antes citada, ella pueda efectivamente concretarse.

122 Dijo allí el Sr. Viera-Gallo (Sesión 20 de la Cámara de Diputados, de 30 de julio de 1996): "Creo que el proyecto amerita complementarse con artículos más precisos respecto de los datos personales, de la actividad policial, de antecedentes comerciales y judiciales". 